\title{
Reservoirs and Transmission Pathways of Resistant Indicator Bacteria in the Biotope Pig Stable and along the Food Chain: A Review from a One Health Perspective
}

\author{
Ricarda Maria Schmithausen ${ }^{1, *(\mathbb{D}}$, Sophia Veronika Schulze-Geisthoevel ${ }^{2}$, Céline Heinemann ${ }^{2}{ }^{\mathbb{D}}$, \\ Gabriele Bierbaum ${ }^{3}$, Martin Exner ${ }^{1}$, Brigitte Petersen ${ }^{2}$ and Julia Steinhoff-Wagner ${ }^{2}$ \\ 1 Institute for Hygiene and Public Health, University Hospital Bonn, 53127 Bonn, Germany; \\ martin.exner@ukbonn.de \\ 2 Institute of Animal Science, Preventive Health Management Group, University of Bonn, Katzenburgweg 7-9, \\ 53115 Bonn, Germany; Sophia.Schulze-Geisthoevel@lwk.nrw.de (S.V.S.-G.); \\ celine.heinemann@uni-bonn.de (C.H.); b-petersen@uni-bonn.de (B.P.); jste@itw.uni-bonn.de (J.S.-W.) \\ 3 Institute for Medical Microbiology, Immunology and Parasitology, University Hospital of Bonn, \\ 53127 Bonn, Germany; g.bierbaum@uni-bonn.de \\ * Correspondence: ricarda.schmithausen@ukbonn.de; Tel.: +49-228-287-13452
}

Received: 1 September 2018; Accepted: 22 October 2018; Published: 31 October 2018

\begin{abstract}
The holistic approach of "One Health" includes the consideration of possible links between animals, humans, and the environment. In this review, an effort was made to highlight knowledge gaps and various factors that contribute to the transmission of antibiotic-resistant bacteria between these three reservoirs. Due to the broad scope of this topic, we focused on pig production and selected "indicator bacteria". In this context, the role of the bacteria livestock-associated methicillin-resistant Staphylococcus aureus (LA-MRSA) and extended spectrum beta-lactamases carrying Escherichia coli (ESBL-E) along the pig production was particularly addressed. Hotspots of their prevalence and transmission are, for example, pig stable air for MRSA, or wastewater and manure for ESBL-E, or even humans as vectors in close contact to pigs (farmers and veterinarians). Thus, this review focuses on the biotope "stable environment" where humans and animals are both affected, but also where the end of the food chain is not neglected. We provide basic background information about antibiotics in livestock, MRSA, and ESBL-bacteria. We further present studies (predominantly European studies) in tabular form regarding the risk potentials for the transmission of resistant bacteria for humans, animals, and meat differentiated according to biotopes. However, we cannot guarantee completeness as this was only intended to give a broad superficial overview. We point out sustainable biotope approaches to try to contribute to policy management as critical assessment points in pig housing conditions, environmental care, animal health, and food product safety and quality as well as consumer acceptance have already been defined.
\end{abstract}

Keywords: MRSA; ESBL-E; pigs; transmission; antibiotic resistance; one health

\section{Introduction}

The use of antibiotics in human and veterinary medicine and their dissemination in the environment have favored the emergence and spread of antibiotic-resistant microorganisms [1-5]. For example, both extended-spectrum betalactamase-producing Escherichia coli (ESBL-E) [6,7] and livestock-associated methicillin-resistant Staphylococcus aureus (LA-MRSA) have already been separately isolated at different stages of the pork production chain [8-11]. Hence, there has been 
an ongoing debate regarding the potential sources, transmission routes, and risk factors of the continuous spread of MRSA and ESBL-E between animals, humans, and the environment [12-16]. Thus, they are also perceived as a potential threat to public health [17-23]. Therefore, in this review, methicillin-resistant Staphylococcus aureus (MRSA) and ESBL-E have been used as "indicator" bacteria with possible zoonotic potential and occurrence in both the stable biotopes and healthcare sector and community [24]. Consequently, farmers have been confronted with several consequences of this problem: The potential danger of animal colonization with drug-resistant bacteria for (i) humans living on or in the vicinity of farms [25-27], and (ii) for consumers of animal products [3,28-31]. The intended audience of this review is farmers of intensive pig production systems worldwide as well as healthcare workers, as humans living and working in close contact with pigs and patients in rural areas have been found to be colonized with LA-MRSA [25,32-38]. On the other hand, in the food chain, meat products can serve as potential transmission factors of ESBL-E from animals to humans [29,39-41].

Furthermore, the global spread of multidrug-resistant Enterobacteriaceae may be linked to wastewater from hotspots like hospitals and/or intensive livestock production settings in Germany and worldwide $[15,16]$. Consequently, the stable environment (air, wastewater, etc.) needs to be considered as a reservoir and source of the dissemination of multidrug-resistant bacteria. Notably, bacteria not only persists on/in the living animal, but also on surfaces that are in contact with the animals (compartment walls and equipment) [42]. In correlation with this, LA-MRSA bacteria were detected by Friese et al. [43] in dust samples from the investigated breeding farms in Germany and in the stable air of a fattening farm, while ESBL-Escherichia coli isolates have been isolated from pig livestock production sites [44]. Furthermore, in the farm environment, both commensal and environmental bacteria serve as reservoirs for the transfer of antimicrobial resistance genes to pathogenic bacteria [45,46]. Pietsch et al. [47] found isolates of distinct $E$. coli clonal lineages in all three reservoirs: Human, animal, and food in Germany. Thus, it is assumed that the contribution of the animal biotope in terms of antimicrobial resistance in humans is not negligible [48].

Therefore, a holistic approach in the sense of "One Health" needs to be integrated into interdisciplinary research at the interface between humans and animals and their common environment [49-52]. In the framework of sustainable biotope infection control measures in pig housing conditions, hygienic stable environment, animal health, and food product safety to reduce the prevalence of resistant bacteria remains challenging in pig production [53].

\section{Background Information}

\subsection{Antibiotic Use in Livestock Production}

The first cases of antimicrobial resistance occurred in the late 1930's [54]. From that point until now, the production of food animals has been associated with large farms, a high density of animals, and in this respect, an improvement in disease management [2].

In a report on antibiotic consumption and resistance in Germany in 2015 (GERMAP), tetracycline, sulfonamide, and betalactam antibiotics (penicillin, first to fourth generation cephalosporin, and the betalactamase inhibitors) [55] were found to be the most commonly used antibiotics in veterinary medicine [56]. The total consumption of around 1706 tons of antibiotics used in the veterinary field in 2011 decreased to 733 tons in 2017 [57,58]. It can be assumed that the reduction was not only based on the EU ban, but on the basis of governmental and private antibiotic monitoring programs. However, the causal relationship between the decrease in resistance rates and the decrease in antibiotic use, observed on behalf of the patient on the basis of the quantities administered and/or the frequency of treatment, cannot be examined on the basis of the available data. Metaphylactic therapy (in which high doses of antibiotics are usually given for a short period) is still preferred in the standard management of some highly organized and efficient management systems due to the optimized disease prevention rates $[59,60]$. The adaptation of bacterial metabolism to antimicrobial agents can be forced by under-dosing and the non-achievement of required blood and tissue levels over several days. 
To avoid the selection of drug-resistant bacteria, it is necessary to relate the dosage of antibiotics to body mass and perform several repeat applications [61]. Further data has shown a correlation between the frequency of treatment and the occurrence of multidrug-resistant bacteria. The higher the treatment frequency (the average number of days each animal in the herd is treated with antibiotics), the higher the rate of resistance identified in isolates from animals and animal products $[62,63]$. Fundamentally, animal protection laws demand that animals with infections have the right to (medical) treatment [64]. Furthermore, the use of antibiotics is indicated for the maintenance of a balanced pig's health and its physical condition $[65,66]$.

\subsection{Characteristics of Multidrug-Resistant Bacteria (MRSA and ESBL-E)}

\subsubsection{MRSA}

S. aureus is a Gram-positive, coagulase-positive bacterium. S. aureus demonstrates a high robustness of months for desiccation, heat, UV radiation, and various disinfectants [67]. S. aureus can transiently or persistently colonize the skin and mucous membranes of the respiratory tract of humans and animals [68]. Colonization alone does not cause symptoms, but can lead to an increased risk for secondary infections: superficial skin lesions and soft tissue infections, invasive life-threatening bloodstream infections, and sepsis [67]. Methicillin-resistant Staphylococcus aureus (MRSA) strains acquire their resistance by transferring the mobile genetic element, SCCmec [69]. The resistance is based on the mecA gene on the SCCmec coding for the $78 \mathrm{kDa}$ alternative penicillin binding protein (PBP2a) [70]. The PBP2a has a very low binding affinity for all betalactam antibiotics. This allows the PBP2a to synthesize the cross-links of the peptidoglycan of the bacterial cell wall without being inhibited by methicillin and any traditional beta-lactam antibiotics [71]. However, new "5th generation" cephalosporins (ceftaroline and ceftobiprole) have a high affinity for this PBP, resulting in enhanced activity against methicillin-resistant S. aureus [72-74]. MRSA in humans was first isolated in the United Kingdom and Denmark after penicillinase-stable betalactam methicillin was introduced in 1959 [75,76]. In animals, MRSA was identified in 1972 [77]. Three different MRSA types linked with human infection can be classified based on their occurrence and distribution patterns: hospital-associated MRSA (HA-MRSA), health care-associated community MRSA (HCA-MRSA), and community-associated MRSA (CA-MRSA) [78,79]. The fourth category is called livestock-associated MRSA (LA-MRSA) and is associated with livestock as well as the humans who are in close contact with the livestock [78]. LA-MRSA has retained a pathogenic potency for humans $[80,81]$ although some virulence factors have been lost [78]. This underlines the potential of "bidirectional zoonotic exchange", which adds risks to public health [78]. Most LA-MRSA strains are classified as clonal lineage CC398 [79,82]. Price et al. [78] assumed that clonal lineages of LA-MRSA CC398 originated from human methicillin-sensitive Staphylococcus aureus (MSSA), which has adapted to livestock animals $[78,83]$.

\subsubsection{ESBL and Resistance Genes}

Extended-spectrum betalactamases (ESBLs) and the less common AmpC enzyme are able to hydrolyze a broader spectrum of betalactam antibiotics than the original betalactamases from which they are derived. ESBLs inactivate betalactam antibiotics with an oxyimino group such as oxyimino-cephalosporin (e.g., ceftazidime and cefotaxime) and the oxyimino-monobactam aztreonam [84,85]. ESBL and AmpC enzymes can combine to expand the resistance profile to include betalactamase inhibitors and even carbapenems [86]. Paterson et al. [87] also described ciprofloxacin resistance as being highly associated with ESBL-producing strains [87]. A further increase in resistance is provided by carbapenemases (e.g., VIM [Verona integron-encoded metallo-betalactamase], NDM [New Delhi metallo-betalactamase], OXA-48 [oxacillin resistant]) [88], which are betalactamases that are able to hydrolyze the carbapenem reserve antibiotics (imipenem, meropenem, and ertapenem) $[89,90]$. The most common types of ESBL enzymes detected in 
Enterobacteriaceae are the following: Temoneira (TEM)-type betalactamase, cefotaximase-Munich (CTX-M)-type betalactamase, sulfhydryl variable (SHV)-type betalactamase, and oxacillin resistant (OXA)-type betalactamase [91]. Currently, the most common worldwide CTX-M-type enzymes can be classified into five main groups depending on their amino acid sequence: CTX-M-1, CTX-M-2, CTX-M-8, CTX-M-9, and CTX-M-25 [13,92-94]. There are more than 40 different CTX-M types assigned to the five main groups [95]. The enzyme that is most widely distributed between human Enterobacteriaceae is CTX-M-15, which has also been detected in E. coli from pigs and poultry $[96,97]$. The genes for ESBL (bla horizontal transfer [100]. Therefore, apart from direct transmission in Enterobacteriaceae, it is of particular interest that resistance genes can be transferred with the help of plasmids to other pathogenic and apathogenic microorganisms. They encode a variety of resistance genes [101]. MGEs appear in a huge variety: Transposons, phages, plasmids, chromosomal resistance cassettes, and others, which can be taken up by bacteria in different biotopes [102]. However, the role of antibiotic resistance genes and their exchange of resistance genes between the human and animal microflora and between the environment is not completely known [103].

\subsection{Bioavailability and Transmission Potential of Antibiotic-Resistant Bacteria}

The following aspects can be discussed to influence the spread and bioavailability of drug-resistant bacteria in different reservoirs in Table S1 in the Supplementary Material.

\section{Reservoirs and Transmission Pathways of LA-MRSA and ESBL-E}

\subsection{Transmission Pathways}

The epidemiology and mechanisms of emergence and spread of antimicrobial resistance and antibiotic-resistant bacteria are diverse and several possible pathways in different systems exist for their transmission. Valentin et al. [104] indicated that the same subtypes of isolates were detected in isolates from human and livestock and companion animal populations, suggesting a possible exchange of bacteria or bacterial genes. Figure 1 presents some possible transmission pathways of antibiotic-resistant bacteria between human and animal vectors and between reservoirs (air, dust, water, manure, food, etc.) as well as exposure routes in their biotopes (stable, abattoir, etc.). Here, the term "biotope" is defined according to Nehring and Albrecht [105] and Lötzli [106] as the living space of a community of species.

Nevertheless, many transmission routes are still unclear. Therefore, in the following passages, a selection of possible transmission pathways in different biotopes and reservoirs will be demonstrated using the selected bacteria MRSA and ESBL-E. We used both MRSA and ESBL-producing E. coli (ESBL-E) as indicators to evaluate the movement of antibiotic-resistant bacteria in the environment [24] as Staphylococcus aureus occurs in both the mucous membrane of humans and animals and is very resistant to the environment. The MRSA strain CC398 is known to be transferred via direct contact between animals [107] and humans [25,108-110], as well as through the environment [111], particularly airborne transmission [43,112]. On the other hand, Escherichia coli is frequently used as indicator bacteria in the animal sector and in environmental hygiene. Additionally, due to its association with swine and pork, we decided to use the resistant variant ESBL-E [113,114]. In the following sections, the different sources and reservoirs, especially within the stable environment, are presented and discussed in more detail regarding the different transmission potentials. 

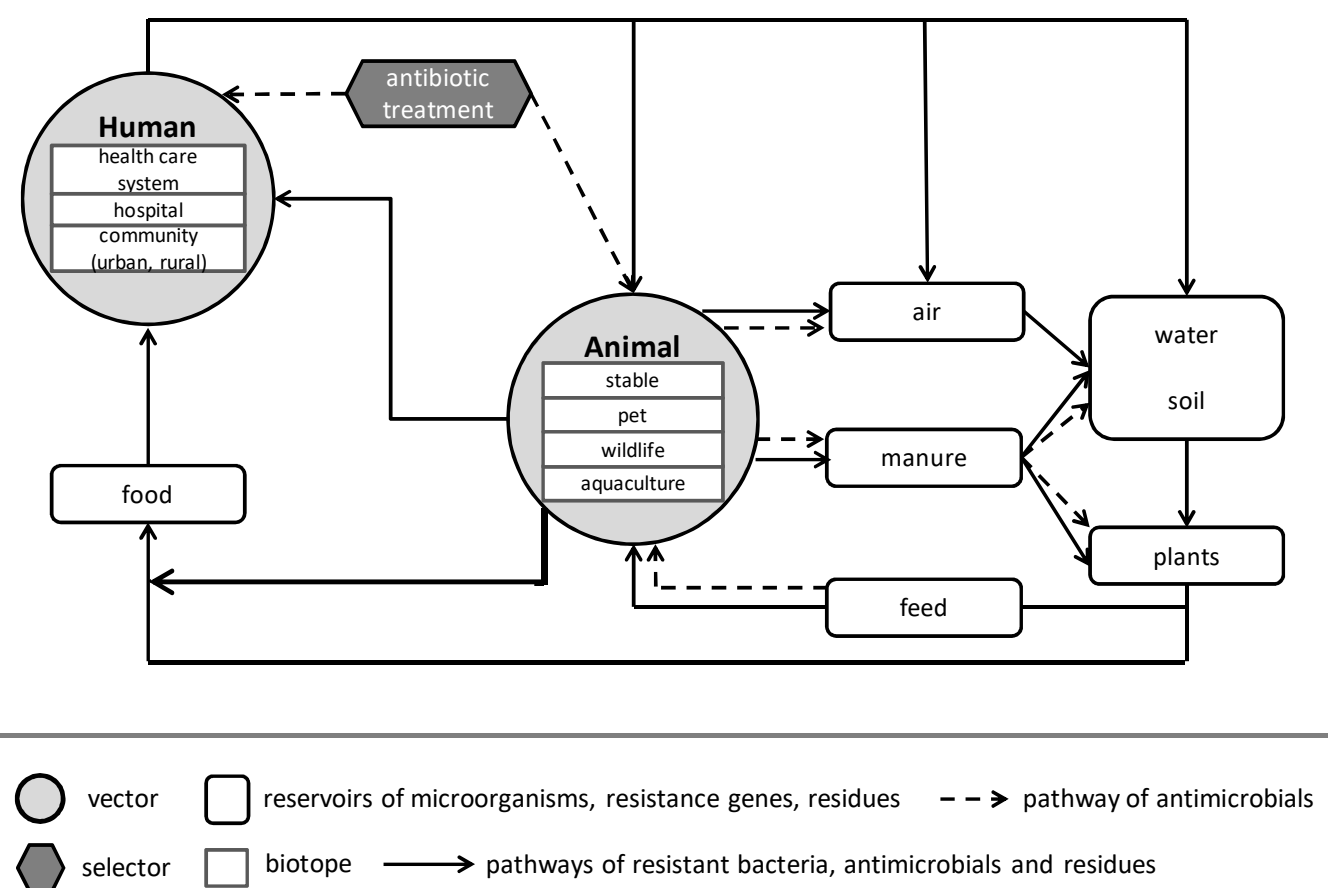

Figure 1. Some possible routes of exposure and transmission pathways of antibiotic-resistant bacteria and antimicrobial resistance between different reservoirs and biotopes.

\subsection{LA-MRSA and ESBL-E in Humans in the Stable Biotope}

The administration of antibiotics in humans and animals selects resistant strains within the microflora and enables colonization of the mucosa with new isolates. Animal strains may be able to transiently colonize human indigenous microflora (and vice versa) and transfer resistance genes [115]. Thus, the human respiratory and gastrointestinal tract can be reservoirs for bacteria with antibiotic resistance [116] (Table S2). Humans working in the stable environment make contact with different resistant strains which can act as vectors in different biotopes [117]: Farmers and veterinarians belong to the stable's biotope [118]. Pig farmers and veterinarians belong to this defined risk group [119]. Table S2 gives an overview over the occurrence of MRSA and ESBL-E rates in farmers and veterinarians in Europe and possible transmission pathways. Nevertheless, the importance of drug-resistant Staphylococcus aureus and/or E. coli strains isolated from the animal biotope has not yet been quantified or evaluated. However, it is assumed that the contribution of the animal biotope in terms of antimicrobial resistance in humans is not negligible [48]. Kraemer et al. [120] even showed associations between antibiotic use and resistant bacteria carriage.

\subsection{LA-MRSA and ESBL-E in Pigs}

Possible sources for the transmission of drug-resistant bacteria and/or antimicrobial resistances include direct contact between animals on the farm and within compartments [121,122] or via pig trading [9,10] in livestock vehicles [123] within or between regions, and the introduction of new animals in herds [124,125]. Pigs can also be colonized during transportation between pig production steps or on their way to the abattoir $[8,126]$. Until now, the LA-MRSA CC398 strain has been found in all stages of the food chain, varying between European countries (Table S3). Other risk factors are reported to be associated with the occurrence of multidrug-resistant bacteria are for antimicrobial use, purchase of gilts, and hygiene measures [127,128]. Generally, the effectiveness of the cleaning and disinfection methods used on commercial pig farms needs to be evaluated in more detail $[129,130]$.

Table S3 gives an overview of several studies describing the different possibilities of the transmission of antibiotic-resistant bacteria (MRSA and ESBL-E) between pigs. 


\subsection{Reservoir Stable Environment}

Studies on the agricultural environment and the food chain have revealed that pathogen reservoirs also exist in the environment outside their animal host [129,131-134]. In farm environments, commensal, and environmental bacteria may be reservoirs for the transfer of antimicrobial resistance genes to pathogenic bacteria [97,135-138].

\subsubsection{LA-MRSA and ESBL-E in Air and Dust}

Dynamic processes influencing the spread of bacteria in the biotope of the animal stable are presented in Figure 2.

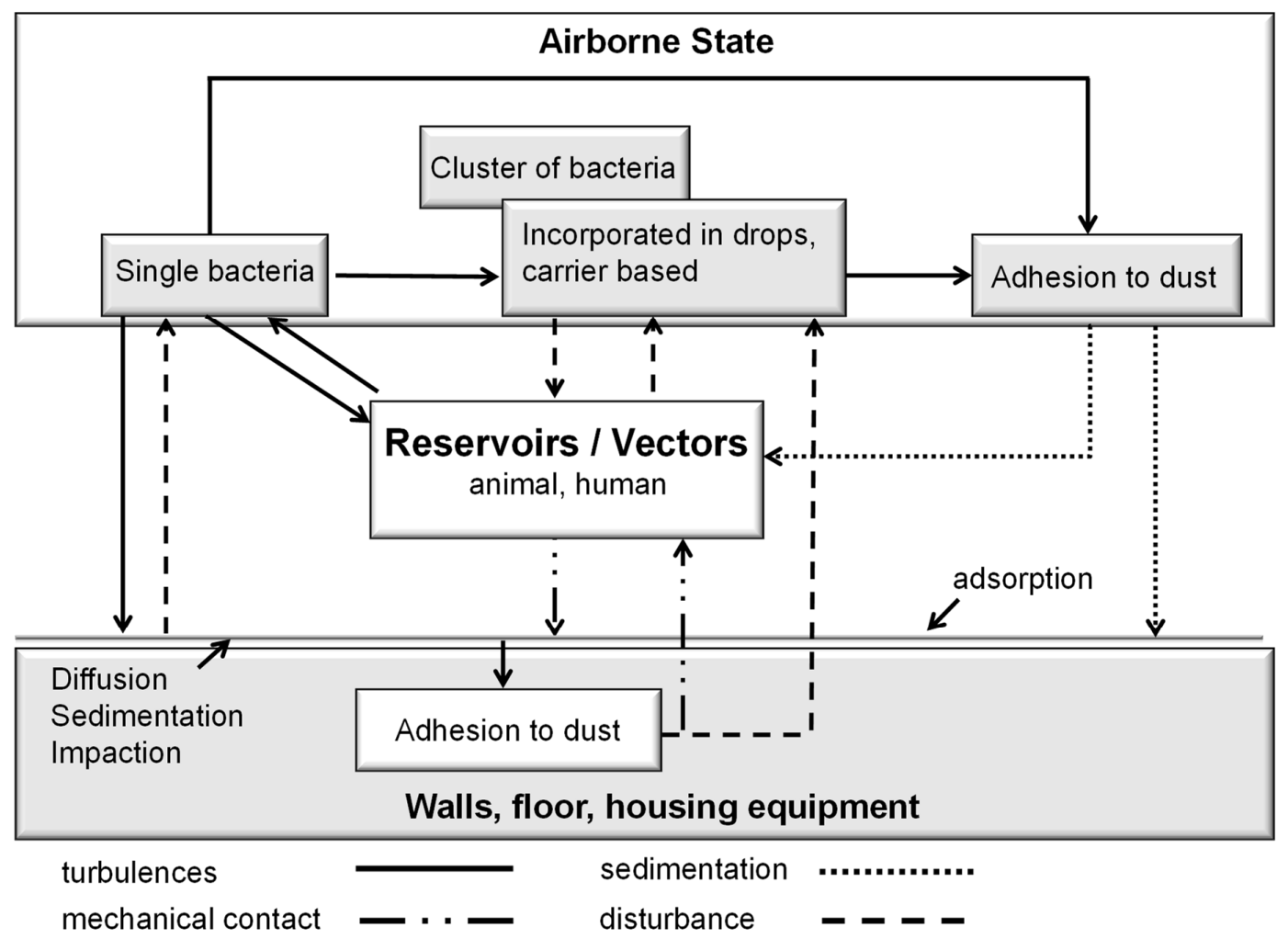

Figure 2. Dynamic processes of bacteria in the biotope of the animal stable (modified according to Müller et al. [139]). Bacteria can spread from their source via different dynamic processes:

- Turbulence: Spread of bacteria due to air turbulence;

- Mechanical contact: Transmission of bacteria by direct contact (passive via stable equipment or active via persons/animals);

- Sedimentation: Reduction of circulation from the airborne state and subsequent deposit;

- Re-suspension: Bacteria not primarily and actively transported by air flow; and

- Re-entrainment: Re-return of already sedimented bacteria to the air [139].

In the pig stable, about $80 \%$ of airborne bacteria are staphylococci (Gram positive) [140] and $0.5 \%$ [141] or even 5\% [142] are coliform bacteria such as E. coli (Gram negative). The imbalance between Gram-positive and Gram-negative bacteria is attributed to the lower survival time of Gram-negative bacteria in their airborne condition [141]. S. aureus can disperse in the air as directly suspendable airborne particles. However, they are most often attached to and carried by dust particles [141]. Once the microorganisms get into the air, they prefer to merge into larger clusters or adhere to larger dust particles. Airborne bacteria return via air turbulence or by sedimentation to their reservoirs on stable surfaces or are acquired by animals or humans [126,128,143]. In contrast, coliform bacteria, 
which are excreted in feces, are mechanically bound to stable surfaces and/or litter and feed [144]. Only after the animal feces have dried out, and due to air turbulence by animal activities, does the whirling dust and dirt particles raise them in the stable air. The level of contamination of stable air by both airborne and coliform bacteria depends on both the animal and stable environment including the density, age, and activity of animals, the ventilation system, the quantity of dust [145], the humidity of the surfaces, and air as well as air turbulence. Survival of intestinal bacteria depends on the environmental conditions outside the animal organism. Survival rates of coliforms are best in the immediate vicinity of the animal and, therefore, in feces and fecal contaminated surfaces, whereas the detection rate in air immediately decreases [146-148]. The bacterial concentration in the air is based on physical processes (e.g., air flow and sedimentation) and on the organisms' biological viability. Influencing factors are temperature, humidity, UV radiation, air change rate, noxious gas concentration, and the organisms' aerodynamic shape [63,149].

Environmental contamination with MRSA was identified in the study by Weese et al. [150]. Friese et al. [43] determined that $85.2 \%$ of pig stables in Germany were LA-MRSA positive in the air. They also identified dust as an important factor for the occurrence of MRSA in the air. Drug-resistant S. aureus could be identified inside and outside the pig stables and originated from contaminated dust [151]. The dissemination of MRSA between pigs within a farm by air was based on a positive association of samples from pigs and the environment [43]. Agersø et al. [112] indicated a high sensitivity of air samples equal to the within-herd prevalence. Therefore, they recommended air sampling for initial testing or even screening of herds. Bos et al. [152] and Gilbert et al. [111] even confirmed a strong association between nasal ST398 MRSA carriage in people working on the farms for $>20 \mathrm{~h}$ per week and MRSA air levels. In people working in the barns $<20 \mathrm{~h}$ per week, there was a strong association between nasal carriage and the number of working hours. This study showed that working in the lairage area or scalding and dehairing area were the major risk factors for MRSA carriage in pig slaughterhouse workers, while the overall prevalence of MRSA carriage was low. Occupational exposure to MRSA decreased along the slaughter line, and the risk of carriage showed a parallel decrease. Heinemann et al. [153] showed that a working time of three-to-six hours could be enough for positive findings of nasal colonization with MRSA. However, it is unknown whether the presence of LA-MRSA is a result of the carriage or retention of MRSA-contaminated dust. Nevertheless, the persistence of LA-MRSA CC398 in humans depends on the intensity of animal contact [109]. Several studies have investigated dust and air samples from pig farms. An overview of some of these studies and their data is given in Table S4.

The main message of all the presented studies (in Table S4) is that exposure to the stable environment and air in pig farms is often contaminated with LA-MRSA, and can act as a transmission source for humans, which is an important determinant for nasal carriage, especially in this highly exposed group of farmers. This is next to the duration of the contact with animals. Intervention measures should therefore also target the reduction of ST398 MRSA air levels including the improvement of environmental and operating parameters of air quality and pig performance $[154,155]$. In contrast, only a few studies have been performed on the spread of ESBL-E in the stable environment such as by dust and air in pig settings [126,156-158]. Laube et al. [159] assumed dust to be a major source for the transmission and spread of ESBL-E within stables and during the release of animals (especially poultry) from stables. They found a high prevalence of ESBL-E in the pooled feces and dust samples obtained on broiler chicken farms [159]. Von Salviati et al. [157] identified the transmission potential between ESBL-E between pig farmers and their surroundings (surfaces, barn, and ambient air). However, the detection of ESBL/AmpC-E. coli in stable air and ambient environment was low and also found ESBL/AmpC-E. coli on surfaces in the vicinity (see details in Table S4). Furthermore, they proved emission via slurry and transmission via flies. Hoffmann [160] hypothesized a possible transmission of CTX-M-1 subtypes to humans via the inhalation of contaminated dust particles during exposure in the stable environment. This assumption was confirmed by the study of Dohmen et al. [158], 
who found that CTX-M-1 carriage in pig farmers and the presence of CTX-M-1 in dust were associated, indicating that air transmission of CTX-M 1 might be possible on pig farms.

In summary, the transmission pathway of ESBL-Enterobacteriaceae via air and/or dust spread via the airborne route or via different vectors seems possible [127]. Otherwise, it is not possible to distinguish between the two transmission pathways of direct contact between humans and animals and the indirect airborne transmission pathway [160]. Contaminated manure presented the major emission source for ESBL/AmpC-producing E. coli on pig farms [157].

\subsubsection{LA-MRSA and ESBL-E in Water, Wastewater and Manure}

Water contaminated with antibiotic-resistant bacteria is an important reservoir for the emergence and spread of resistance mechanisms and mobile genetic elements [161,162]. Ingestion and dealing with contaminated water can result in the colonization of the gastrointestinal tract of humans and animals [163]. Thus, water constitutes not only a way for the dissemination of antibiotic-resistant organisms among human and animal populations as drinking water is produced from surface water, but also a major route by which resistance genes are introduced to natural bacterial ecosystems. In such systems, nonpathogenic bacteria can serve as a reservoir of resistance genes [162]. Lupo et al. [161] and Schwartz et al. [164] highlighted horizontal gene transfer by transduction as the main mechanism conferring drug resistance in drinking water, surface water, and wastewater. Several other studies have reported the presence of drug-resistant bacteria and resistance genes in fresh drinking water, rivers, and sewage in Europe and all over the world [16,44,165-171]. Nevertheless, to date, more and more information about the risks of contamination of livestock drinking water with antibiotic-resistant bacteria have been provided [128,172,173]. Pletinckx et al. [174] did not find any evidence of MRSA-positive isolates in animal drinking water on pig and poultry farms, while environmental samples (dust, animal feed, and manure) and samples from pigs and farmers were contaminated with MRSA. However, MRSA has been found in contaminated feed and trough water $[130,172]$. Thus, water sources might facilitate the transmission of MRSA between different animals [175]. Feed and troughs also represent possible sources of exposure to foodborne coliform bacteria like E. coli [176]. Animals potentially face daily exposure to bacterial contamination from these sources. Nevertheless, LeJeune et al. [172] indicated that the degree of bacterial contamination was associated with potentially controllable management factors. Water systems in stables represent a complex ecosystem that is affected by multiple factors. These factors influence the persistence and the effects of bacteria in drinking water (pipelines and troughs) [172,177]. The multiple factors are diverse: entry of biomass into the system promotes biofilm growth as a medium for microorganisms, installation defects, backward spread of bacteria, high temperature, etc. Therefore, it is essential to control the quality of the animals' drinking water at regular intervals (at least once a year) [178]. Hartung and Kamphues [179] determined basic practical and species-specific aspects in housing conditions including the water collection and distribution system as basic requirements for sustainable livestock and housing management $[178,179]$. Heinemann et al. [130] found high bacterial loads in animal drinkers after cleaning and disinfection, which could lead to a vertical transfer of pathogens to newly arriving pigs. In this context, Heinemann et al. [130] indicated that decontamination strategies such as intensive cleaning and disinfection were effective at reducing the levels of Enterobacteriaceae on stable floors. Nevertheless, residual contamination remains in the environment and on the surfaces of troughs and drinkers $[129,130]$. The findings of Jutkina et al. [180] therefore indicate that exposure to sub-lethal concentrations of certain antimicrobials may contribute to the emerging problem of antibiotic resistance not only through selection of certain resistance phenotypes, but also by means of stimulating transfer of antimicrobial resistance traits directly. Schwartz et al. [164] assumed a possible transfer from wastewater and surface water to drinking water distribution systems. Hölzel et al. [181] expected that antibiotic-resistant bacteria could also reach the food chain via human and animal manure applications. Thus, the possible risk for the transmission of antibiotic-resistant bacteria, resistance genes, and antibiotics from human wastewater or animal manure to the environment, 
including drinking waters and the food chain, cannot be neglected. Some studies have reported multidrug-resistant pathogens in the soil and water of farm environments. The ESBL-variants detected corresponded to those previously found in animals or humans living in a farm environment [182,183] (Table S5). To date, several non-European studies have reported multidrug-resistant pathogens in the vegetables, soil, and water of farm environments. The ESBL-variants detected corresponded to those previously found in animals or humans living in a farm environment [182,183]. Vital et al. [184] proved that multidrug-resistant isolates were observed in irrigation water, soil, and vegetables in urban farms, indicating that water serves as a possible route for a wide distribution across all types of borders. All of the presented studies commonly demonstrate (molecular) homology analysis of CTX-M-producing E. coli isolates collected from water and/or swine, and/or human, implying that multidrug-resistant pathogens in the aquatic environment might derive from both humans and animals $[44,185]$. However, contaminated slurry was presented as the major emission source for ESBL/AmpC-producing E. coli in pig fattening farms [158]. Several other studies identified ESBL strains in manure samples from pig farms (Table S5). However, a possible link between the prevalence of ESBL-E in hospitals and other sources such as local food, water, or animal sources has not been identified [186].

\subsection{LA-MRSA and ESBL-E in the Food Chain: Abattoir Biotope}

Abattoirs can be possible sources of drug-resistant bacteria [187]: Carry-over of resistant bacteria at the time of slaughter, the hygiene related to the slaughter processes, meat processing hygiene, and retail handling [188,189] (Table S6). Pietsch et al. [47] found isolates of distinct E. coli clonal lineages in all three reservoirs of human, animal, and food in Germany. However, a direct clonal relationship of isolates from food animals and humans was only noticeable for a few cases. All foodborne outbreaks have been caused by enteropathogens. The role of the ESBL-producing Enterobacteriaceae in these persons was considered as commensal flora. Thus, in comparison to the general population, humans involved in food processing need to be considered as very important intermediate reservoirs and vectors for ESBL genes remaining in food retailers contaminated with ESBL-producing bacteria [190]. Normanno et al. [191] clearly demonstrated the need for improved hygiene standards to reduce the risk of occupational and foodborne infection linked to the handling/consumption of raw pork containing resistant bacteria like MRSA and ESBL-Enterobacteriaceae.

\section{Sustainable Biotope Approaches}

\subsection{Animal Health in the Livestock Biotope}

The origin of many health problems in pig production is very complex in nature [192]. Diseases that occur in a multi-factor system such as pig production are not only defined by one factor, but by the interplay of a variety of processes that take place in the animate and inanimate environments of the animal and within the animal [192]. Künneken [143] described the interaction between several factors in the stable environment in his model (Figure 3).

In modern intensive livestock, the following infection-promoting and infection-inhibiting factors can influence the balance of the stable biotope:

1. A high number of passages of host pathogens with potentially increased virulence within herds;

2. Higher rates of the adhesion of pathogens;

3. The rapid spread of pathogens via direct host contact, food, water, air, and living vectors;

4. The use of high-performance animals that are more sensitive to environmental stressors;

5. The neglect of hygiene principles, e.g., sufficient drying times during cleaning and disinfection; and

6. The reduced possibility of individual health control and animal observation [143]. 


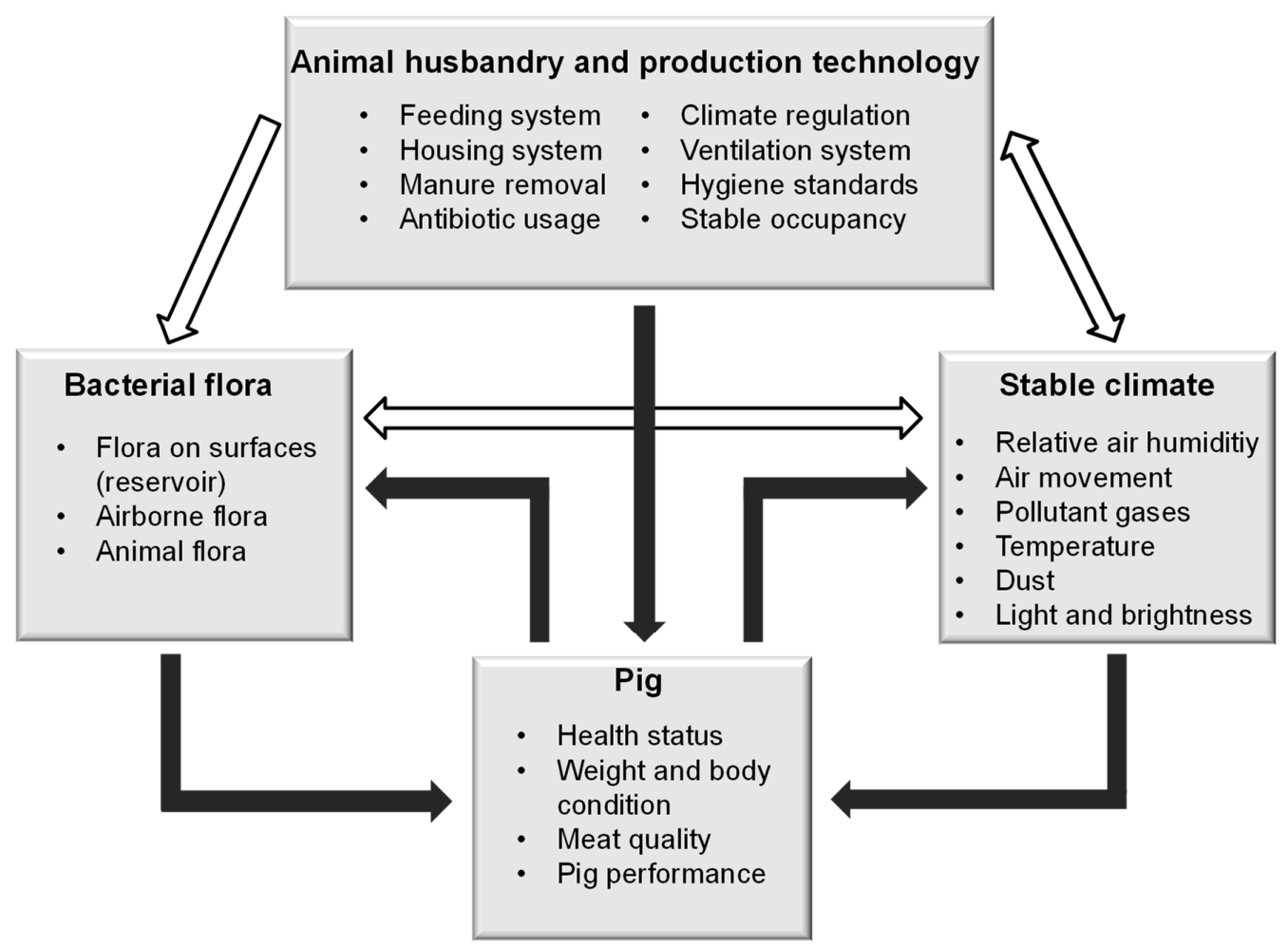

Figure 3. Relationships between animate and inanimate factors in environmental reservoirs (modified according to Künneken [143]).

These infection-promoting and infection-inhibiting factors are involved in constantly changing processes in the stable biotope. If there is a summation of many infection-promoting factors in one or all of the three systems, a chain of events is initiated with the possible outcome of an infectious disease [192]. Walker et al. [193] identified three aspects in the problem of increasing the resistance of bacteria in, for example, a pig producing system: Pigs have difficulties developing and stabilizing their individual natural barrier and immune response (stable-specific immunity) against the increase and spread of pathogens caused by a high pig density or when pigs are introduced into a new stable with a foreign pig population. These and other actions can trigger chronic stress responses with the pigs becoming more susceptible to infections that are caused by potentially infectious commensal bacteria [194]. Thus, closed systems show lower colonization rates with multidrug-resistant bacteria than those farms with a high rate of incoming pigs (maybe even from one or even more than two different suppliers), which interferes with stable immunity [10,195]. Thielen et al. [196] referred to animal health in livestock as a balance between infection pressure and the animals' immune systems.

\subsection{Preventive Health Management: Part of Quality Management}

At the beginning of the last century, animals were only treated when they were clearly suffering from a disease or if their lives were acutely threatened. Whereas in recent decades, the concept of "integrated veterinary herd health care" has been established, focusing on the combination of systematic animal health management of the entire animal population for the prevention and early detection of diseases. Today, the focus is on the implementation to react to any deviation from the normal state as fast as possible given that diseases, even if they occur without visible symptoms, impair the well-being of the animals, and thus have effects on eating and drinking behavior [197].

From the perspective of protecting consumer health, it is important to prevent the entry of pathogens from animal origins that are likely to cause human zoonosis [198]. Strategies for the maintenance of animal health afford a direct contribution towards optimizing consumer health protection [199]. In recent years, research projects have focused on the implementation and 
organization of intra and inter-farm health management systems in meat-production chains [200-210]. The main task of health management is the maintenance of animal health at all stages of animal production. Animal health not only has special significance for the production of healthy food, but also for the economical optimization of the various production stages, namely farrowing, nursery, and finishing [201,204,205]. According to Berns [200] and Welz [208], diseases are considered as process errors and quality-reducing effects in terms of quality management. Therefore, preventive quality management focuses on health precautions on livestock farms [211].

Similar to human medicine, animal health management can be divided into three levels (Table 1) [212].

Table 1. Definition of the three levels of prevention (according to Schulze Althoff, [212]).

\begin{tabular}{cl}
\hline Level & \multicolumn{1}{c}{ Definition } \\
\hline Primary prevention & $\begin{array}{l}\text { Structural, group-based and individual measures to prevent the } \\
\text { occurrence of disturbances }\end{array}$ \\
\hline Secondary prevention & $\begin{array}{l}\text { Preventive measures initiated once the pathogen has been identified in } \\
\text { order to prevent progression of the disturbance }\end{array}$ \\
\hline Tertiary prevention & $\begin{array}{l}\text { Measures to prevent aggravation of the disturbance and mitigate the } \\
\text { effects of the disturbance }\end{array}$ \\
\hline
\end{tabular}

According to Berns [200], the main priorities of preventive animal health management are the following:

- Detect diseases while still in the subclinical stage;

- Prevent infections from progressing to a clinical stage and stop the spread from a single animal to the whole herd; and

- Identify and promptly eliminate stressors and risks to animal health from the environment.

Consequently, to ensure food safety and quality, the traditional quality control at the end of the production process needs to be supplemented by control inspections at an incoming and at an intermediate level—when selling and purchasing piglets, finishing pigs, and at slaughter [204]. To assure food safety and consumer protection, only healthy pigs that originate from farms with a certified health status should be slaughtered [212]. Health and quality assurance in pork production encompasses:

- Pig supplying farms;

- Networks of primary producers; and

- Slaughtering, processing, and distribution [205,213].

Thus, animal health management is deemed to be an integral part of quality management in a food supply chain, all the way to grocery retail stores $[198,214]$. Coordinating these measures with several enterprises along the value-added pork chain defines the inter-farm chain-oriented quality management [215]. The concept of a quality management system is defined as systematic planning, implementation, and documentation with an influence on the quality of a product [206,209]. The driving force is each participating enterprise's awareness that by improving its own quality management, it can make the quality management efforts of other enterprises in the value chain more efficient. This enables the maximization of the profits of the enterprises that compose the value chain $[216,217]$.

\section{3. "One Health" Crossing Biotopes}

The interdisciplinary cooperation in solving complex health problems is intended to create incentives for system innovation [50]. The resistance problem is one of many examples that can be perfectly addressed within the "One Health" approach [218-221]. In the case of pork production, 
this means considering humans and animals in the "livestock" biotope, as well as the "food processing and transport" and "health care system" biotopes, are all interconnected via the environment.

Every pig production farm that produces animals for sale constitutes a separate biotope. Pigs, throughout their life, are often moved from one biotope to another. The production of pigs usually includes four transfers and changes of stables. Each farm involved constitutes a geographical and organizational unit within the chain [209]. Nevertheless, it should not be underestimated that on finishing farms, the source of the colonization of pigs, whether acquired at the current stage or during farrowing or nursery stages, often cannot be determined [222]. De Neeling et al. [222] and other authors $[223,224]$ have reported that pigs, colonized at the farrowing or nursery farm, carry their microbial load over to the finishing stage. In this context, the livestock biotope greatly benefits from inter-farm measures that detect and promptly reduce the risk of infections spreading from one stage of production to the next $[201,214]$. The establishment of monitoring systems and the certification of farms according to their health status use this approach. Hereby, single and intra and inter-farm audits as well as monitoring for specific pathogens (e.g., for LA-MRSA and ESBL-E) have been implemented [201,204,205]. With the renewal of the German Drug Act (16th AMG-Novelle) in 2014, antibiotic consumption in farm animal production is monitored to reduce its usage. Exceeding the farm-specific biannual therapeutic frequency beyond the $75 \%$ quantile obligates livestock owners to submit a written plan of measures to the public veterinary authority. Four years after its implementation, an in-depth scientific evaluation of the antibiotic monitoring is still due [225]. Epidemiological trends within a value-added chain can, according to Schulze-Geisthövel et al. (2015), be recognized, and farm comparisons such as industry marketing can be made by the common use of investigation data. Salmonella monitoring, for instance, is regularly included in the coordinated investigations between supplier farms and abattoirs [226,227]. Schulze Althoff [209] and Düsseldorf [201] stressed that it would make sense along the pig production chain for a receiving inspection to be referred to the supplier, an intermediate checkup referred to the farm, and a final inspection referred to the customer. This is because the carcass can be contaminated through the slaughtering process as well as by the intestinal contents of the slaughtered animals [7]. Therefore, all E.U. member states are obligated by guideline 2003/99/EG to monitor for zoonosis and zoonotic bacteria. In the context of zoonosis monitoring, representative data regarding the occurrence of zoonotic bacteria has for years been acquired in the most important food supplying animal species and products to measure the infection risk for consumers from consuming food.

Furthermore, many decision-makers in politics and science have demanded and promoted from agricultural science, veterinarian and human medicine, and environmental sciences, a common collaborative holistic strategy (the "One Health" approach) against the spread of antibiotic-resistant bacteria $[51,220]$.

\section{Final Remarks, Recommendations and Future Directions}

The holistic collaborative "One Health" approach between human medicine and agricultural sciences has advanced the risk assessment of the dynamics of MRSA and ESBL-E transmission pathways as well as that of human exposure related to livestock production (particularly pigs) and processing. The impact of the importance of these "indicator bacteria" is still under debate; especially as new resistance problems and transferable resistance genes are emerging. For example, the global rise of Carbapenemase-producing Enterobacteriaceae has resulted in the increased use of Colistin resistance and is associated with the risk of emerging resistance. This concerns agriculture just as much as human medicine and requires round table discussions on the prudent and sustainable use of antibiotics on both sides. As this review has demonstrated, these discussions will no longer only focus on humans and animals and their food products. The focus of "One Health" will expand and focus on the environmental aspect. On the other hand, in environmental hotspots with their own dynamics and links to the reservoirs and vectors, and "animal" and "human" in different biotopes are currently crystallizing out. 
This review tried to make a small contribution to the better understanding of possible transmission pathways between the presented reservoirs and highlights the following aspects:

- Healthy animals do not need antibiotic medication, thus further suppressing the risk of the occurrence of non-pathogenic resistant bacteria. The constant administration of antibiotics to animals will destroy potential antibiotics. Therefore, to save existing potential antibiotics, the government, physicians, and farm industries should limit the prescription of antibiotics to prevent antibiotic resistance, and people should not easily obtain access to self-medicated antibiotics, especially in developing countries.

- Farmers and veterinarians come into contact with antimicrobial-resistant bacteria from pigs within the stable environment. Strong associations between the isolation of resistant commensal bacteria (both MRSA and ESLB-E) and contact with pigs and even the working hours in the stable could be made.

- However, not only do animals present potential reservoirs or vectors for transferring resistance genes and resistant bacteria, but even farmers and farm workers themselves should also be considered for their transmission potential.

- Thus, aside from organic factors, the inanimate environment such as the stable climate has a substantial influence on the well-being and health status of pigs and the tenacity of bacteria. Air and dust were clearly determined as sources for the contamination of humans and animals mainly with MRSA.

- Wastewater in general (municipal, urban, with clinical and/or agroindustrial influence) serves as a melting pot for the possible horizontal transfer between resistance genes and multidrug-resistant bacteria. Whereas the impact of animal wastewater on surface water has yet to be investigated.

Thus far, resistant bacteria could be isolated with a higher percentage from swine and slaughterhouse wastewater, only indicating the potential role of agricultural wastewater within the context of environmental resistance pollution.

- Many resistant bacteria in animal drinkers could be identified after cleaning and disinfection, which could lead to a vertical transfer of pathogens to newly arriving pigs. Therefore, methods for cleaning performances, especially regarding the water systems in pig stables, should be evaluated.

- A high prevalence of ESBL-E was found in pig manure, indicating a high emission and transmission potential into the stable environment and their surroundings.

- Contamination of meat with ESBL-producing E. coli and MRSA is no longer surprising. However, the growing diversity of ESBL-E indicates a growing dissemination of ESBL-genes in E. coli in meat products from porcine origin.

Some aspects could improve our ability to mitigate the spread of resistances and would be a useful supplement to the already existing health management initiatives. Possible strategies for the enhancement of individual defense mechanisms and control of the resistance status could be the following:

- Limit the purchase of new pigs to those that are accompanied with health certificates from the supply farms.

- Determine the MRSA/ESBL status (similar to the Salmonella monitoring), take part in a continued health-monitoring program and create financial incentives for reduction measures.

- Use workshops and training to transfer scientific knowledge and sensitize for reduction measures.

However, permanent colonization should be distinguished from transient colonization. Interventions-as already implemented in the health care system-may prevent transient colonization and may hence be a useful control of MRSA not only in the hospital, but also in the stable environment. 
In general, knowledge and information about the biotope-crossing potential of multidrug-resistant bacteria and antibiotic resistances should be the most important approach within the "One Health" concept. Several articles in this review demonstrated that these aspects are not yet anchored in the teaching and education of farmers, (medical and agriculture) students, multipliers, and policy makers. In summary, these approaches contribute to a larger goal of achieving the early recognition of antimicrobial resistance in bacterial livestock pathogens. Therefore, future scientific efforts should clarify the persistence and spread of highly resistant bacteria in the environment, especially in the stable and aquatic environment and their interface.

Within this framework, the implications of the "One Health" approach could have a positive impact on all sustainable future strategies.

Supplementary Materials: The following are available online at http:/ /www.mdpi.com/2071-1050/10/11/3967/s1. Table S1: Discussion of eight factors possibly influencing transmission and bioavailability of drug-resistant bacteria. Table S2: Overview of LA-MRSA and ESBL-E in humans in the stable biotope. Abbreviations for the transmission pathways: $\mathrm{HH}=$ Human to Human, $\mathrm{AA}=$ Animal to Animal, $\mathrm{HA}=$ Human to Animal, $\mathrm{AH}=\mathrm{Animal}$ to Human, $\mathrm{HE}=$ Human to Environment, $\mathrm{EH}=$ Environment to Human, $\mathrm{AE}=$ Animal to Environment, $\mathrm{EA}=$ Environment to Animal, $\mathrm{EE}=$ Environment to Environment, $\mathrm{FH}=$ Food to Human, HF = Human to Food, $\mathrm{EF}=$ Environment to Food, AF = Animal to Food. Abbreviations for the countries: NL = Netherlands, ESP = Spain, IT = Italy, EU = Europe, DEN = Denmark, UK = United Kingdom, GER = Germany, BEL = Belgium, $\mathrm{FR}=$ France, $\mathrm{USA}=$ United States of America, CHE = Switzerland, HKG = Hong Kong. Table S3: Overview over several studies describing the different possibilities of the transmission of antibiotic-resistant bacteria (MRSA and ESBL-E) between pigs. Abbreviations for the transmission pathways: $\mathrm{HH}=$ Human to Human, $\mathrm{AA}=\mathrm{Animal}$ to Animal, $\mathrm{HA}=$ Human to Animal, $\mathrm{AH}=$ Animal to Human, $\mathrm{HE}=$ Human to Environment, $\mathrm{EH}=$ Environment to Human, $\mathrm{AE}=$ Animal to Environment, $\mathrm{EA}=$ Environment to Animal, $\mathrm{EE}=$ Environment to Environment, $\mathrm{FH}=$ Food to Human, HF = Human to Food, EF = Environment to Food, AF = Animal to Food. Abbreviations for the countries: NL = Netherlands, ESP = Spain, IT = Italy, EU = Europe, DEN = Denmark, UK = United Kingdom, GER = Germany, BEL = Belgium, FR = France, USA = United States of America, CHE = Switzerland, INT = international (worldwide). Table S4: Overview of LA-MRSA and ESBL-E in air and dust in the stable environment. Abbreviations for the transmission pathways: $\mathrm{HH}=\mathrm{Human}$ to Human, AA = Animal to Animal, $\mathrm{HA}=$ Human to Animal, $\mathrm{AH}=$ Animal to Human, $\mathrm{HE}=$ Human to Environment, $\mathrm{EH}=$ Environment to Human, $\mathrm{AE}=$ Animal to Environment, $\mathrm{EA}=$ Environment to Animal, $\mathrm{EE}=$ Environment to Environment, $\mathrm{FH}=$ Food to Human, $\mathrm{HF}=$ Human to Food, $\mathrm{EF}=$ Environment to Food, $\mathrm{AF}=$ Animal to Food. Abbreviations for the countries: HUN = Hungary, NL = Netherlands, ESP = Spain, IT = Italy, EU = Europe, CHN = China, $\mathrm{NOR}=$ Norway, DEN $=$ Denmark, UK $=$ United Kingdom, GER = Germany, BEL $=$ Belgium, FR $=$ France, USA = United States of America, CHE = Switzerland. Table S5: Table overview over LA-MRSA and ESBL-E in Water, Wastewater and Manure of pig production facilities. Abbreviations for the transmission pathways: $\mathrm{HH}=$ Human to Human, $\mathrm{AA}=$ Animal to Animal, $\mathrm{HA}=$ Human to Animal, $\mathrm{AH}=$ Animal to Human, $\mathrm{HE}=\mathrm{Human}$ to Environment, $\mathrm{EH}=$ Environment to Human, $\mathrm{AE}=$ Animal to Environment, $\mathrm{EA}=$ Environment to Animal, $\mathrm{EE}=$ Environment to Environment, $\mathrm{FH}=$ Food to Human, HF = Human to Food, EF = Environment to Food, $\mathrm{AF}=$ Animal to Food. Abbreviations for the countries: NL = Netherlands, ESP = Spain, IT = Italy, EU = Europe, $\mathrm{CHN}=$ China, NOR = Norway, DEN = Denmark, UK = United Kingdom, GER = Germany, BEL = Belgium, FR $=$ France, USA = United States of America, CHE = Switzerland, PHL = Philippines. Table S6: Table overview over LA-MRSA and ESBL-E in the Food Chain: Abattoir Biotope and Human vectors in Pig Meat Processing. Abbreviations for the transmission pathways: $\mathrm{HH}=$ Human to Human, AA = Animal to Animal, $\mathrm{HA}=\mathrm{Human}$ to Animal, $\mathrm{AH}=$ Animal to Human, $\mathrm{HE}=$ Human to Environment, $\mathrm{EH}=$ Environment to Human, $\mathrm{AE}=\mathrm{Animal}$ to Environment, EA = Environment to Animal, EE = Environment to Environment, FH = Food to Human, $\mathrm{HF}=$ Human to Food, $\mathrm{EF}=$ Environment to Food, $\mathrm{AF}=$ Animal to Food. Abbreviations for the countries: $\mathrm{CAN}=$ Canada, $\mathrm{NL}=$ Netherlands, $\mathrm{ESP}=$ Spain, $\mathrm{IT}=$ Italy, EU = Europe, $\mathrm{CHN}=$ China, $\mathrm{NOR}=\mathrm{Norway}$, $\mathrm{DEN}=$ Denmark, UK = United Kingdom, GER = Germany, BEL = Belgium, FR = France, USA = United States of America, $\mathrm{CHE}=$ Switzerland, JAP = Japan, AUS = Austria.

Author Contributions: Each author made substantial contributions to: Conceptualisation: R.M.S., S.V.S.-G., G.B., M.E. and B.P.; Formal analysis: R.M.S. and J.S.-W.; Investigation: R.M.S. and S.V.S.-G.; Methodology: R.M.S, S.V.S.-G. and C.H.; Project administration: R.M.S. and B.P.; Supervision: M.E.; Validation: R.M.S and J.S.-W.; Visualization: R.M.S. and S.V.S.-G.; Writing—original draft: R.M.S.; Writing—review \& editing: R.M.S., C.H., G.B. and J.S.-W.

Funding: "This research received no external funding" at the Institute of Animal Sciences at the University of Bonn and the Institutes of Medical Microbiology, Immunology and Parasitology, Hygiene and Public Health at the University Hospital Bonn.

Conflicts of Interest: The authors declare no conflict of interest. 


\section{References}

1. Gilchrist, M.J.; Greko, C.; Wallinga, D.B.; Beran, G.W.; Riley, D.G.; Thorne, P.S. The potential role of concentrated animal feeding operations in infectious disease epidemics and antibiotic resistance. Environ. Health Perspect. 2007, 115, 313-316. [CrossRef] [PubMed]

2. Mathew, A.G.; Cissell, R.; Liamthong, S. Antibiotic resistance in bacteria associated with food animals: A United States perspective of livestock production. Foodborne Pathog. Dis. 2007, 4, 115-133. [CrossRef] [PubMed]

3. Threlfall, E.J.; Ward, L.R.; Frost, J.A.; Willshaw, G.A. The emergence and spread of antibiotic resistance in food-borne bacteria. Int. J. Food Microbiol. 2000, 62, 1-5. [CrossRef]

4. Pruden, A.; Larsson, D.G.; Amézquita, A.; Collignon, P.; Brandt, K.K.; Graham, D.W.; Lazorchak, J.M.; Suzuki, S.; Silley, P.; Snape, J.R.; et al. Management options for reducing the release of antibiotics and antibiotic resistance genes to the environment. Environ. Health Perspect. 2013, 121, 878-885. [CrossRef] [PubMed]

5. Landers, T.F.; Cohen, B.; Wittum, T.E.; Larson, E.L. A review of antibiotic use in food animals: Perspective, policy, and potential. Public Health Rep. 2012, 127, 4-22. [CrossRef] [PubMed]

6. Escudero, E.; Vinué, L.; Teshager, T.; Torres, C.; Moreno, M.A. Resistance mechanisms and farm-level distribution of fecal Escherichia coli isolates resistant to extended-spectrum cephalosporins in pigs in Spain. Res. Vet. Sci. 2010, 88, 83-87. [CrossRef] [PubMed]

7. Hansen, K.H.; Damborg, P.; Andreasen, M.; Nielsen, S.S.; Guardabassi, L. Carriage and fecal counts of cefotaxime M-producing Escherichia coli in pigs: A longitudinal study. Appl. Environ. Microbiol. 2013, 79, 794-798. [CrossRef] [PubMed]

8. Broens, E.M.; Graat, E.A.; Van der Wolf, P.J.; Van de Giessen, A.W.; De Jong, M.C. Transmission of methicillin resistant Staphylococcus aureus among pigs during transportation from farm to abattoir. Vet. J. 2011, 189, 302-305. [CrossRef] [PubMed]

9. Broens, E.M.; Graat, E.A.; van der Wolf, P.J.; van de Giessen, A.W.; van Duijkeren, E.; Wagenaar, J.A.; van Nes, A.; Mevius, D.J.; de Jong, M.C. MRSA CC398 in the pig production chain. Prev. Vet. Med. 2011, 98, 182-189. [CrossRef] [PubMed]

10. van Duijkeren, E.; Ikawaty, R.; Broekhuizen-Stins, M.J.; Jansen, M.D.; Spalburg, E.C.; de Neeling, A.J.; Allaart, J.G.; van Nes, A.; Wagenaar, J.A.; Fluit, A.C. Transmission of methicillin-resistant Staphylococcus aureus strains between different kinds of pig farms. Vet. Microbiol. 2008, 126, 383-389. [CrossRef] [PubMed]

11. Schulze-Geisthövel, S.; Schmithausen, R.; Stemmer, F.; El-Sade, M.; Hoerauf, A.; Exner, M.; Bierbaum, G.; Bekeredjian-Ding, I.; Petersen, B. Occurrence of MRSA and ESBL in different habitats and different stages of the pork production chain. In Proceedings of the DACH Epidemiologietagung "Tiergesundheit und Ökonomie", Zürich, Schweiz, 3-5 September 2014.

12. Hunter, P.A.; Dawson, S.; French, G.L.; Goossens, H.; Hawkey, P.M.; Kuijper, E.J.; Nathwani, D.; Taylor, D.J.; Teale, C.J.; Warren, R.E.; et al. Antimicrobial-resistant pathogens in animals and man: Prescribing, practices and policies. J. Antimicrob. Chemother. 2010, 65 (Suppl. 1), i3-i17. [CrossRef] [PubMed]

13. Hawkey, P.M.; Jones, A.M. The changing epidemiology of resistance. J. Antimicrob. Chemother. 2009, 64 (Suppl. 1), i3-i10. [CrossRef] [PubMed]

14. Li, X.Z.; Mehrotra, M.; Ghimire, S.; Adewoye, L. Beta-Lactam resistance and beta-lactamases in bacteria of animal origin. Vet. Microbiol. 2007, 121, 197-214. [CrossRef] [PubMed]

15. Müller, A.; Stephan, R.; Nüesch-Inderbinen, M. Distribution of virulence factors in ESBL-producing Escherichia coli isolated from the environment, livestock, food and humans. Sci. Total Environ. 2016, 541, 667-672. [CrossRef] [PubMed]

16. Westphal-Settele, K.; Konradi, S.; Balzer, F.; Schönfeld, J.; Schmithausen, R. The environment as a reservoir for antimicrobial resistance: A growing problem for public health? Bundesgesundheitsblatt Gesundheitsforschung Gesundheitsschutz 2018, 61, 533-542. [CrossRef] [PubMed]

17. Mehndiratta, P.L.; Bhalla, P. Use of antibiotics in animal agriculture \& emergence of methicillin-resistant Staphylococcus aureus (MRSA) clones: Need to assess the impact on public health. Indian J. Med. Res. 2014, 140, 339-344. [PubMed] 
18. Liverani, M.; Waage, J.; Barnett, T.; Pfeiffer, D.U.; Rushton, J.; Rudge, J.W.; Loevinsohn, M.E.; Scoones, I.; Smith, R.D.; Cooper, B.S.; et al. Understanding and managing zoonotic risk in the new livestock industries. Environ. Health Perspect. 2013, 121, 873-877. [CrossRef] [PubMed]

19. Mather, A.E.; Matthews, L.; Mellor, D.J.; Reeve, R.; Denwood, M.J.; Boerlin, P.; Reid-Smith, R.J.; Brown, D.J.; Coia, J.E.; Browning, L.M.; et al. An ecological approach to assessing the epidemiology of antimicrobial resistance in animal and human populations. Proc. Biol. Sci. 2012, 279, 1630-1639. [CrossRef] [PubMed]

20. EFSA. Assessment of the Public Health Significance of Methicillin Resistant Staphylococcus Aureus (MRSA) in Animals and Foods; EFSA: Parma, Italy, 2009.

21. Da Costa, P.M.; Loureiro, L.; Mator, A.J.F. Transfer of multidrug-resistant bacteria between intermingled ecological niches: The interface between humans, animals and the environment. Int. J. Environ. Res. Public Health 2013, 10, 278-294. [CrossRef] [PubMed]

22. BfR. ESBL-Bildende Bakterien in Lebensmitteln und Deren Übertragbarkeit auf den Menschen; Bundesinstitut für Risikobewertung (BfR): Berlin, Germany, 2010.

23. Willyard, C. The drug-resistant bacteria that pose the greatest health threats. Nature 2017, 543, 15. [CrossRef] [PubMed]

24. Guenther, S.; Ewers, C.; Wieler, L.H. Extended-spectrum beta-lactamases producing E. coli in wildlife, yet another form of environmental pollution? Front. Microbiol. 2011, 2, 246. [CrossRef] [PubMed]

25. Cuny, C.; Nathaus, R.; Layer, F.; Strommenger, B.; Altmann, D.; Witte, W. Nasal colonization of humans with methicillin-resistant Staphylococcus aureus (MRSA) CC398 with and without exposure to pigs. PLoS ONE 2009, 4, e6800. [CrossRef] [PubMed]

26. Deiters, C.; Günnewig, V.; Friedrich, A.W.; Mellmann, A.; Köck, R. Are cases of Methicillin-resistant Staphylococcus aureus clonal complex (CC) 398 among humans still livestock-associated? Int. J. Med. Microbiol. 2015, 305, 110-113. [CrossRef] [PubMed]

27. Van den Bogaard, A.E.; Stobberingh, E.E. Epidemiology of resistance to antibiotics. Links between animals and humans. Int. J. Antimicrob. Agents 2000, 14, 327-335. [CrossRef]

28. Marshall, B.M.; Levy, S.B. Food animals and antimicrobials: Impacts on human health. Clin. Microbiol. Rev. 2011, 24, 718-733. [CrossRef] [PubMed]

29. Aarestrup, F.M.; Hasman, H.; Agersø, Y.; Jensen, L.B.; Harksen, S.; Svensmark, B. First description of blaCTX-M-1-carrying Escherichia coli isolates in Danish primary food production. J. Antimicrob. Chemother. 2006, 57, 1258-1259. [CrossRef] [PubMed]

30. Liebana, E.; Batchelor, M.; Hopkins, K.L.; Clifton-Hadley, F.A.; Teale, C.J.; Foster, A.; Barker, L.; Threlfall, E.J.; Davies, R.H. Longitudinal farm study of extended-spectrum beta-lactamase-mediated resistance. J. Clin. Microbiol. 2006, 44, 1630-1634. [CrossRef] [PubMed]

31. De Boer, E.; Zwartkruis-Nahuis, J.T.; Wit, B.; Huijsdens, X.W.; de Neeling, A.J.; Bosch, T.; van Oosterom, R.A.; Vila, A.; Heuvelink, A.E. Prevalence of methicillin-resistant Staphylococcus aureus in meat. Int. J. Food Microbiol. 2009, 134, 52-56. [CrossRef] [PubMed]

32. Wulf, M.W.; Verduin, C.M.; van Nes, A.; Huijsdens, X.; Voss, A. Infection and colonization with methicillin resistant Staphylococcus aureus ST398 versus other MRSA in an area with a high density of pig farms. Eur. J. Clin. Microbiol. Infect. Dis. 2012, 31, 61-65. [CrossRef] [PubMed]

33. Van Cleef, B.A.; Verkade, E.J.; Wulf, M.W.; Buiting, A.G.; Voss, A.; Huijsdens, X.W.; van Pelt, W.; Mulders, M.N.; Kluytmans, J.A. Prevalence of livestock-associated MRSA in communities with high pig-densities in The Netherlands. PLoS ONE 2010, 5, e9385. [CrossRef] [PubMed]

34. Monaco, M.; Pedroni, P.; Sanchini, A.; Bonomini, A.; Indelicato, A.; Pantosti, A. Livestock-associated methicillin-resistant Staphylococcus aureus responsible for human colonization and infection in an area of Italy with high density of pig farming. BMC Infect. Dis. 2013, 13, 258. [CrossRef] [PubMed]

35. Aubry-Damon, H.; Grenet, K.; Sall-Ndiaye, P.; Che, D.; Cordeiro, E.; Bougnoux, M.E.; Rigaud, E.; Le Strat, Y.; Lemanissier, V.; Armand-Lefèvre, L.; et al. Antimicrobial resistance in commensal flora of pig farmers. Emerg. Infect. Dis. 2004, 10, 873-879. [CrossRef] [PubMed]

36. Köck, R.; Schaumburg, F.; Mellmann, A.; Köksal, M.; Jurke, A.; Becker, K.; Friedrich, A.W. Livestock-associated methicillin-resistant Staphylococcus aureus (MRSA) as causes of human infection and colonization in Germany. PLoS ONE 2013, 8, e55040. [CrossRef] [PubMed] 
37. Köck, R.; Bischoff, M.; Cuny, C.; Eckmanns, T.; Fetsch, A.; Harmsen, D.; Goerge, T.; Oberheitmann, B.; Schwarz, S.; Selhorst, T.; et al. The burden of zoonotic MRSA colonization and infection in Germany. Berl. Munch. Tierarztl. Wochenschr. 2014, 127, 384-398. [PubMed]

38. Bisdorff, B.; Scholhölter, J.L.; Claußen, K.; Pulz, M.; Nowak, D.; Radon, K. MRSA-ST398 in livestock farmers and neighbouring residents in a rural area in Germany. Epidemiol. Infect. 2012, 140, 1800-1808. [CrossRef] [PubMed]

39. Johnson, J.R.; Kuskowski, M.A.; Smith, K.; O’Bryan, T.T.; Tatini, S. Antimicrobial-resistant and extraintestinal pathogenic Escherichia coli in retail foods. J. Infect. Dis. 2005, 191, 1040-1049. [CrossRef] [PubMed]

40. Overdevest, I.; Willemsen, I.; Rijnsburger, M.; Eustace, A.; Xu, L.; Hawkey, P.; Heck, M.; Savelkoul, P.; Vandenbroucke-Grauls, C.; van der Zwaluw, K.; et al. Extended-spectrum $\beta$-lactamase genes of Escherichia coli in chicken meat and humans, The Netherlands. Emerg. Infect. Dis. 2011, 17, 1216-1222. [CrossRef] [PubMed]

41. Jakobsen, L.; Spangholm, D.J.; Pedersen, K.; Jensen, L.B.; Emborg, H.D.; Agersø, Y.; Aarestrup, F.M.; Hammerum, A.M.; Frimodt-Møller, N. Broiler chickens, broiler chicken meat, pigs and pork as sources of ExPEC related virulence genes and resistance in Escherichia coli isolates from community-dwelling humans and UTI patients. Int. J. Food Microbiol. 2010, 142, 264-272. [CrossRef] [PubMed]

42. Weese, J.S.; Rousseau, J. Attempted eradication of methicillin-resistant staphylococcus aureus colonisation in horses on two farms. Equine Vet. J. 2005, 37, 510-514. [CrossRef] [PubMed]

43. Friese, A.; Schulz, J.; Hoehle, L.; Fetsch, A.; Tenhagen, B.A.; Hartung, J.; Roesler, U. Occurrence of MRSA in air and housing environment of pig barns. Vet. Microbiol. 2012, 158, 129-135. [CrossRef] [PubMed]

44. Hu, Y.Y.; Cai, J.C.; Zhou, H.W.; Chi, D.; Zhang, X.F.; Chen, W.L.; Zhang, R.; Chen, G.X. Molecular typing of CTX-M-producing escherichia coli isolates from environmental water, swine feces, specimens from healthy humans, and human patients. Appl. Environ. Microbiol. 2013, 79, 5988-5996. [CrossRef] [PubMed]

45. Blake, D.P.; Hillman, K.; Fenlon, D.R.; Low, J.C. Transfer of antibiotic resistance between commensal and pathogenic members of the Enterobacteriaceae under ileal conditions. J. Appl. Microbiol. 2003, 95, 428-436. [CrossRef] [PubMed]

46. Martinez, J.L. The role of natural environments in the evolution of resistance traits in pathogenic bacteria. Proc. Biol. Sci. 2009, 276, 2521-2530. [CrossRef] [PubMed]

47. Pietsch, M.; Irrgang, A.; Roschanski, N.; Brenner Michael, G.; Hamprecht, A.; Rieber, H.; Käsbohrer, A.; Schwarz, S.; Rösler, U.; Kreienbrock, L.; et al. Whole genome analyses of CMY-2-producing Escherichia coli isolates from humans, animals and food in Germany. BMC Genom. 2018, 19, 601. [CrossRef] [PubMed]

48. Hammerum, A.M.; Heuer, O.E. Human health hazards from antimicrobial-resistant Escherichia coli of animal origin. Clin. Infect. Dis. 2009, 48, 916-921. [CrossRef] [PubMed]

49. Wilcox, B.; Kueffer, C. Transdisciplinarity in EcoHealth: Status and future prospects. Ecohealth 2008, 5, 1-3. [CrossRef] [PubMed]

50. Zinsstag, J.; Schelling, E.; Waltner-Toews, D.; Tanner, M. From “one medicine" to "one health" and systemic approaches to health and well-being. Prev. Vet. Med. 2011, 101, 148-156. [CrossRef] [PubMed]

51. Haxton, E.; Sinigoj, S.; Betson, M.; Riviere-Cinnamond, A. Evidence-based added value of One Health: The Network for Evaluation of One Health (NEOH). One Health Sweden 2015. Available online: http://neoh. onehealthglobal.net/wp-content/uploads/sites/2/2015/01/NEOH-UPDATES-NOV-2015.pdf (accessed on 23 October 2018). [CrossRef] [PubMed]

52. Köck, R.; Kreienbrock, L.; van Duijkeren, E.; Schwarz, S. Antimicrobial resistance at the interface of human and veterinary medicine. Vet. Microbiol. 2017, 200, 1-5. [CrossRef] [PubMed]

53. Denis, O.; Suetens, C.; Hallin, M.; Catry, B.; Ramboer, I.; Dispas, M.; Willems, G.; Gordts, B.; Butaye, P.; Struelens, M.J. Methicillin-resistant Staphylococcus aureus ST398 in swine farm personnel, Belgium. Emerg. Infect. Dis. 2009, 15, 1098-1101. [CrossRef] [PubMed]

54. Alanis, A.J. Resistance to antibiotics: Are we in the post-antibiotic era? Arch. Med. Res. 2005, 36, $697-705$. [CrossRef] [PubMed]

55. Smet, A.; Martel, A.; Persoons, D.; Dewulf, J.; Heyndrickx, M.; Herman, L.; Haesebrouck, F.; Butaye, P. Broad-spectrum $\beta$-lactamases among Enterobacteriaceae of animal origin: Molecular aspects, mobility and impact on public health. FEMS Microbiol. Rev. 2010, 34, 295-316. [CrossRef] [PubMed] 
56. GERMAP. GERMAPAntibiotikaresistenz und -verbrauchBericht über den Antibiotikaverbrauch und die Verbreitung von Antibiotikaresistenzen in der Human- und VeterinÄrmedizin in Deutschland; GERMAP/PEG: Langen, Germany, 2015.

57. BMEL. Lagebild zum Antibiotikaeinsatz; BMELV: Bonn, Germany, 2017.

58. BVL. Zweite Datenerhebung zur Antibiotikagabe in der Tiermedizin; BVL: Berlin, Germany, 2017.

59. Callens, B.; Persoons, D.; Maes, D.; Laanen, M.; Postma, M.; Boyen, F.; Haesebrouck, F.; Butaye, P.; Catry, B.; Dewulf, J. Prophylactic and metaphylactic antimicrobial use in Belgian fattening pig herds. Prev. Vet. Med. 2012, 106, 53-62. [CrossRef] [PubMed]

60. Economou, V.; Gousia, P. Agriculture and food animals as a source of antimicrobial-resistant bacteria. Infect. Drug Resist. 2015, 8, 49-61. [CrossRef] [PubMed]

61. Trolldernier, H. Zu Grundlagen der Antibiotikaresistenz. Mh Vet. Med. 1975, 41, $234-237$.

62. Hering, J.; Hille, K.; Frömke, C.; von Münchhausen, C.; Hartmann, M.; Schneider, B.; Friese, A.; Roesler, U.; Merle, R.; Kreienbrock, L. Prevalence and potential risk factors for the occurrence of cefotaxime resistant Escherichia coli in German fattening pig farms-A cross-sectional study. Prev. Vet. Med. 2014, 116, 129-137. [CrossRef] [PubMed]

63. Gothe, C.; Petersen, B. Qualitätsmerkmal Tierwohl; Rhenish Friedrich-Wilhelms University: Bonn, Germany, 2018.

64. TierSchG. Tierschutzgesetz in der Fassung der Bekanntmachung vom 18. Mai 2006. (BGBl. I S. 1206, 1313), das Zuletzt Durch Artikel 141 des Gesetzes vom. März 2017 (BGBl. I S. 626) Geändert Worden ist. 1972. Available online: https://www.tierhyg.vetmed.uni-muenchen.de/tierschutz/tierschutzlinks/ts_ downloads/tschg.pdf (accessed on 23 October 2018).

65. Bollwahn, W. Grauer Arzneimittelmarkt. Aufklären, keine neuen Gesetze. Top Agrar 1981, 9, $63-67$.

66. Aarestrup, F. Sustainable farming: Get pigs off antibiotics. Nature 2012, 486, 465-466. [CrossRef] [PubMed]

67. Quinn, P.; Markey, B.; ME, C.; Donnelly, W.; Leonard, C. Veterinary Microbiology and Microbial Disease; Blackwell Sciences Ltd.: Oxford, UK, 2002.

68. Kenner, J.; O'Connor, T.; Piantanida, N.; Fishbain, J.; Eberly, B.; Viscount, H.; Uyehara, C.; Hospenthal, D. Rates of carriage of methicillin-resistant and methicillin-susceptible Staphylococcus aureus in an outpatient population. Infect. Control Hosp. Epidemiol. 2003, 24, 439-444. [CrossRef] [PubMed]

69. Ito, T.; Okuma, K.; Ma, X.X.; Yuzawa, H.; Hiramatsu, K. Insights on antibiotic resistance of Staphylococcus aureus from its whole genome: Genomic island SCC. Drug Resist. Updat. 2003, 6, 41-52. [CrossRef]

70. Hiramatsu, K.; Cui, L.; Kuroda, M.; Ito, T. The emergence and evolution of methicillin-resistant Staphylococcus aureus. Trends Microbiol. 2001, 9, 486-493. [CrossRef]

71. Pinho, M.G.; Filipe, S.R.; de Lencastre, H.; Tomasz, A. Complementation of the essential peptidoglycan transpeptidase function of penicillin-binding protein 2 (PBP2) by the drug resistance protein PBP2A in Staphylococcus aureus. J. Bacteriol. 2001, 183, 6525-6531. [CrossRef] [PubMed]

72. Alm, R.A.; McLaughlin, R.E.; Kos, V.N.; Sader, H.S.; Iaconis, J.P.; Lahiri, S.D. Analysis of Staphylococcus aureus clinical isolates with reduced susceptibility to ceftaroline: An epidemiological and structural perspective. J. Antimicrob. Chemother. 2014, 69, 2065-2075. [CrossRef] [PubMed]

73. Moisan, H.; Pruneau, M.; Malouin, F. Binding of ceftaroline to penicillin-binding proteins of Staphylococcus aureus and Streptococcus pneumoniae. J. Antimicrob. Chemother. 2010, 65, 713-716. [CrossRef] [PubMed]

74. Lovering, A.L.; Gretes, M.C.; Safadi, S.S.; Danel, F.; de Castro, L.; Page, M.G.; Strynadka, N.C. Structural insights into the anti-methicillin-resistant Staphylococcus aureus (MRSA) activity of ceftobiprole. J. Biol. Chem. 2012, 287, 32096-32102. [CrossRef] [PubMed]

75. De Lencastre, H.; Chung, M.; Westh, H. Archaic strains of methicillin-resistant Staphylococcus aureus: Molecular and microbiological properties of isolates from the 1960s in Denmark. Microb. Drug Resist. 2000, 6, 1-10. [CrossRef] [PubMed]

76. Jevons, M.P. “Celbenin” resistant staphylococci. Br. Med. J. 1961, 1, 124-125. [CrossRef]

77. Devriese, L.A.; Van Damme, L.R.; Fameree, L. Methicillin (cloxacillin)-resistant Staphylococcus aureus strains isolated from bovine mastitis cases. Zentralbl. Veterinarmed. B 1972, 19, 598-605. [CrossRef] [PubMed]

78. Price, L.B.; Stegger, M.; Hasman, H.; Aziz, M.; Larsen, J.; Andersen, P.S.; Pearson, T.; Waters, A.E.; Foster, J.T.; Schupp, J.; et al. Staphylococcus aureus CC398: Host adaptation and emergence of methicillin resistance in livestock. MBio 2012, 3. [CrossRef] [PubMed] 
79. Catry, B.; Van Duijkeren, E.; Pomba, M.C.; Greko, C.; Moreno, M.A.; Pyörälä, S.; Ruzauskas, M.; Sanders, P.; Threlfall, E.J.; Ungemach, F.; et al. Reflection paper on MRSA in food-producing and companion animals: Epidemiology and control options for human and animal health. Epidemiol. Infect. 2010, 138, 626-644. [CrossRef] [PubMed]

80. Witte, W.; Strommenger, B.; Stanek, C.; Cuny, C. Methicillin-resistant Staphylococcus aureus ST398 in humans and animals, Central Europe. Emerg. Infect. Dis. 2007, 13, 255-258. [CrossRef] [PubMed]

81. Fitzgerald, J.R. Livestock-associated Staphylococcus aureus: Origin, evolution and public health threat. Trends Microbiol. 2012, 20, 192-198. [CrossRef] [PubMed]

82. Cuny, C.; Friedrich, A.; Kozytska, S.; Layer, F.; Nübel, U.; Ohlsen, K.; Strommenger, B.; Walther, B.; Wieler, L.; Witte, W. Emergence of methicillin-resistant Staphylococcus aureus (MRSA) in different animal species. Int. J. Med. Microbiol. 2010, 300, 109-117. [CrossRef] [PubMed]

83. Lowder, B.V.; Guinane, C.M.; Ben Zakour, N.L.; Weinert, L.A.; Conway-Morris, A.; Cartwright, R.A.; Simpson, A.J.; Rambaut, A.; Nübel, U.; Fitzgerald, J.R. Recent human-to-poultry host jump, adaptation, and pandemic spread of Staphylococcus aureus. Proc. Natl. Acad. Sci. USA 2009, 106, 19545-19550. [CrossRef] [PubMed]

84. Bradford, P.A. Extended-spectrum beta-lactamases in the 21st century: Characterization, epidemiology, and detection of this important resistance threat. Clin. Microbiol. Rev. 2001, 14, 933-951. [CrossRef] [PubMed]

85. Bradford, P.A.; Petersen, P.J.; Fingerman, I.M.; White, D.G. Characterization of expanded-spectrum cephalosporin resistance in E. coli isolates associated with bovine calf diarrhoeal disease. J. Antimicrob. Chemother. 1999, 44, 607-610. [CrossRef] [PubMed]

86. Bradford, P.A.; Urban, C.; Mariano, N.; Projan, S.J.; Rahal, J.J.; Bush, K. Imipenem resistance in Klebsiella pneumoniae is associated with the combination of ACT-1, a plasmid-mediated AmpC beta-lactamase, and the foss of an outer membrane protein. Antimicrob. Agents Chemother. 1997, 41, 563-569. [CrossRef] [PubMed]

87. Paterson, D.L.; Mulazimoglu, L.; Casellas, J.M.; Ko, W.C.; Goossens, H.; Von Gottberg, A.; Mohapatra, S.; Trenholme, G.M.; Klugman, K.P.; McCormack, J.G.; et al. Epidemiology of ciprofloxacin resistance and its relationship to extended-spectrum beta-lactamase production in Klebsiella pneumoniae isolates causing bacteremia. Clin. Infect. Dis. 2000, 30, 473-478. [CrossRef] [PubMed]

88. Kaase, M. Carbapenemases in gram-negative bacteria. Current data and trends of resistance resulting from the work of national reference centres. Bundesgesundheitsblatt Gesundheitsforschung Gesundheitsschutz 2012, 55, 1401-1404. [CrossRef] [PubMed]

89. Walsh, T.R. Emerging carbapenemases: A global perspective. Int. J. Antimicrob. Agents 2010, 36 (Suppl. 3), S8-S14. [CrossRef]

90. Patel, G.; Bonomo, R.A. Status report on carbapenemases: Challenges and prospects. Expert Rev. Anti Infect. Ther. 2011, 9, 555-570. [CrossRef] [PubMed]

91. Livermore, D.M. Beta-Lactamases in laboratory and clinical resistance. Clin. Microbiol. Rev. 1995, 8, 557-584. [CrossRef] [PubMed]

92. Tham, J.; Walder, M.; Melander, E.; Odenholt, I. Prevalence of extended-spectrum beta-lactamase-producing bacteria in food. Infect. Drug Resist. 2012, 5, 143-147. [CrossRef] [PubMed]

93. Pitout, J.D. Infections with extended-spectrum beta-lactamase-producing enterobacteriaceae: Changing epidemiology and drug treatment choices. Drugs 2010, 70, 313-333. [CrossRef] [PubMed]

94. Naseer, U.; Sundsfjord, A. The CTX-M conundrum: Dissemination of plasmids and Escherichia coli clones. Microb. Drug Resist. 2011, 17, 83-97. [CrossRef] [PubMed]

95. Pitout, J.D.; Gregson, D.B.; Church, D.L.; Elsayed, S.; Laupland, K.B. Community-wide outbreaks of clonally related CTX-M-14 beta-lactamase-producing Escherichia coli strains in the Calgary health region. J. Clin. Microbiol. 2005, 43, 2844-2849. [CrossRef] [PubMed]

96. Smet, A.; Martel, A.; Persoons, D.; Dewulf, J.; Heyndrickx, M.; Catry, B.; Herman, L.; Haesebrouck, F.; Butaye, P. Diversity of extended-spectrum beta-lactamases and class $\mathrm{C}$ beta-lactamases among cloacal Escherichia coli Isolates in Belgian broiler farms. Antimicrob. Agents Chemother. 2008, 52, 1238-1243. [CrossRef] [PubMed] 
97. Tian, G.B.; Wang, H.N.; Zou, L.K.; Tang, J.N.; Zhao, Y.W.; Ye, M.Y.; Tang, J.Y.; Zhang, Y.; Zhang, A.Y.; Yang, X.; et al. Detection of CTX-M-15, CTX-M-22, and SHV-2 extended-spectrum beta-lactamases (ESBLs) in Escherichia coli fecal-sample isolates from pig farms in China. Foodborne Pathog. Dis. 2009, 6, 297-304. [CrossRef] [PubMed]

98. Geser, N.; Stephan, R.; Korczak, B.M.; Beutin, L.; Hächler, H. Molecular identification of extended-spectrum- $\beta$-lactamase genes from Enterobacteriaceae isolated from healthy human carriers in Switzerland. Antimicrob. Agents Chemother. 2012, 56, 1609-1612. [CrossRef] [PubMed]

99. Kiiru, J.; Kariuki, S.; Goddeeris, B.M.; Butaye, P. Analysis of $\beta$-lactamase phenotypes and carriage of selected $\beta$-lactamase genes among Escherichia coli strains obtained from Kenyan patients during an 18-year period. BMC Microbiol. 2012, 12, 155. [CrossRef] [PubMed]

100. Shah, A.A.; Hasan, F.; Ahmed, S.; Hameed, A. Characteristics, epidemiology and clinical importance of emerging strains of Gram-negative bacilli producing extended-spectrum beta-lactamases. Res. Microbiol. 2004, 155, 409-421. [CrossRef] [PubMed]

101. Frost, L.S.; Leplae, R.; Summers, A.O.; Toussaint, A. Mobile genetic elements: The agents of open source evolution. Nat. Rev. Microbiol. 2005, 3, 722-732. [CrossRef] [PubMed]

102. Malachowa, N.; DeLeo, F.R. Mobile genetic elements of Staphylococcus aureus. Cell. Mol. Life Sci. 2010, 67, 3057-3071. [CrossRef] [PubMed]

103. Allen, H.K.; Donato, J.; Wang, H.H.; Cloud-Hansen, K.A.; Davies, J.; Handelsman, J. Call of the wild: Antibiotic resistance genes in natural environments. Nat. Rev. Microbiol. 2010, 8, 251-259. [CrossRef] [PubMed]

104. Valentin, L.; Sharp, H.; Hille, K.; Seibt, U.; Fischer, J.; Pfeifer, Y.; Michael, G.B.; Nickel, S.; Schmiedel, J.; Falgenhauer, L.; et al. Subgrouping of ESBL-producing Escherichia coli from animal and human sources: An approach to quantify the distribution of ESBL types between different reservoirs. Int. J. Med. Microbiol. 2014, 304, 805-816. [CrossRef] [PubMed]

105. Nehring, S.; Albrecht, U. Biotop, Habitat, Mikrohabitat—Ein Diskussionsbeitrag zur Begriffsdefinition. Lauterbonia 2000, 38, 75-84.

106. Lötzli, K. Ökosystem. In Handbuch zur Ökologie; Kuttler: Berlin, Germany, 1993; pp. 288-295. Available online: https:/ / www.zobodat.at/pdf/Lauterbornia_2000_38_0075-0084.pdf (accessed on 30 October 2018).

107. Broens, E.M. Livestock-Associated Methicillin Resistant Staphylococcus Aureus in Pigs-Prevalence, Risk Factors and Transmission Dynamics; Wageningen University: Wageningen, The Netherlands, 2011.

108. Armand-Lefevre, L.; Ruimy, R.; Andremont, A. Clonal comparison of Staphylococcus aureus isolates from healthy pig farmers, human controls, and pigs. Emerg. Infect. Dis. 2005, 11, 711-714. [CrossRef] [PubMed]

109. Graveland, H.; Wagenaar, J.A.; Bergs, K.; Heesterbeek, H.; Heederik, D. Persistence of livestock associated MRSA CC398 in humans is dependent on intensity of animal contact. PLoS ONE 2011, 6, e16830. [CrossRef] [PubMed]

110. Lozano, C.; Aspiroz, C.; Charlez, L.; Gómez-Sanz, E.; Toledo, M.; Zarazaga, M.; Torres, C. Skin lesion by methicillin-resistant Staphylococcus aureus ST398-t1451 in a Spanish pig farmer: Possible transmission from animals to humans. Vector Borne Zoonotic Dis. 2011, 11, 605-607. [CrossRef] [PubMed]

111. Gilbert, M.J.; Bos, M.E.; Duim, B.; Urlings, B.A.; Heres, L.; Wagenaar, J.A.; Heederik, D.J. Livestock-associated MRSA ST398 carriage in pig slaughterhouse workers related to quantitative environmental exposure. Occup. Environ. Med. 2012, 69, 472-478. [CrossRef] [PubMed]

112. Agersø, Y.; Vigre, H.; Cavaco, L.M.; Josefsen, M.H. Comparison of air samples, nasal swabs, ear-skin swabs and environmental dust samples for detection of methicillin-resistant Staphylococcus aureus (MRSA) in pig herds. Epidemiol. Infect. 2014, 142, 1727-1736. [CrossRef] [PubMed]

113. Agersø, Y.; Aarestrup, F.M.; Pedersen, K.; Seyfarth, A.M.; Struve, T.; Hasman, H. Prevalence of extended-spectrum cephalosporinase (ESC)-producing Escherichia coli in Danish slaughter pigs and retail meat identified by selective enrichment and association with cephalosporin usage. J. Antimicrob. Chemother. 2012, 67, 582-588. [CrossRef] [PubMed]

114. Jakobsen, L.; Kurbasic, A.; Skjøt-Rasmussen, L.; Ejrnaes, K.; Porsbo, L.J.; Pedersen, K.; Jensen, L.B.; Emborg, H.D.; Agersø, Y.; Olsen, K.E.; et al. Escherichia coli isolates from broiler chicken meat, broiler chickens, pork, and pigs share phylogroups and antimicrobial resistance with community-dwelling humans and patients with urinary tract infection. Foodborne Pathog. Dis. 2010, 7, 537-547. [CrossRef] [PubMed] 
115. Guardabassi, L. Sixty years of antimicrobial use in animals: what is next? Vet. Rec. 2013, 173, 599-603. [CrossRef] [PubMed]

116. Smet, A.; Martel, A.; Persoons, D.; Dewulf, J.; Heyndrickx, M.; Cloeckaert, A.; Praud, K.; Claeys, G.; Catry, B.; Herman, L.; et al. Comparative analysis of extended-spectrum- $\beta$-lactamase-carrying plasmids from different members of Enterobacteriaceae isolated from poultry, pigs and humans: Evidence for a shared $\beta$-lactam resistance gene pool? J. Antimicrob. Chemother. 2009, 63, 1286-1288. [CrossRef] [PubMed]

117. Wulf, M.W.; Tiemersma, E.; Kluytmans, J.; Bogaers, D.; Leenders, A.C.; Jansen, M.W.; Berkhout, J.; Ruijters, E.; Haverkate, D.; Isken, M.; et al. MRSA carriage in healthcare personnel in contact with farm animals. J. Hosp. Infect. 2008, 70, 186-190. [CrossRef] [PubMed]

118. Vanderhaeghen, W.; Hermans, K.; Haesebrouck, F.; Butaye, P. Methicillin-resistant Staphylococcus aureus (MRSA) in food production animals. Epidemiol. Infect. 2010, 138, 606-625. [CrossRef] [PubMed]

119. Köck, R.; Harlizius, J.; Bressan, N.; Laerberg, R.; Wieler, L.H.; Witte, W.; Deurenberg, R.H.; Voss, A.; Becker, K.; Friedrich, A.W. Prevalence and molecular characteristics of methicillin-resistant Staphylococcus aureus (MRSA) among pigs on German farms and import of livestock-related MRSA into hospitals. Eur. J. Clin. Microbiol. Infect. Dis. 2009, 28, 1375-1382. [CrossRef] [PubMed]

120. Kraemer, J.G.; Pires, J.; Kueffer, M.; Semaani, E.; Endimiani, A.; Hilty, M.; Oppliger, A. Prevalence of extended-spectrum $\beta$-lactamase-producing Enterobacteriaceae and Methicillin-Resistant Staphylococcus aureus in pig farms in Switzerland. Sci. Total Environ. 2017, 603-604, 401-405. [CrossRef] [PubMed]

121. Schouten, J.M.; Bouwknegt, M.; van de Giessen, A.W.; Frankena, K.; De Jong, M.C.; Graat, E.A. Prevalence estimation and risk factors for Escherichia coli O157 on Dutch dairy farms. Prev. Vet. Med. 2004, 64, 49-61. [CrossRef] [PubMed]

122. Correira-Gomes, C.; Economou, T.; Bailey, T.; Brazdil, P.; Vieira-Pinto, M.; Niza-Ribiero, J. Simulation Model for Salmonella Typhimurium on a Farrow-to-Finish herd. In Proceedings of the 10th International Conference on the Epidemiology and Control of Biological, Chemical and Physical Hazards in Pigs and Pork, Lisbon, Portugal, 9-12 September 2013.

123. Grøntvedt, C.A.; Elstrøm, P.; Stegger, M.; Skov, R.L.; Skytt Andersen, P.; Larssen, K.W.; Urdahl, A.M.; Angen, Ø.; Larsen, J.; Åmdal, S.; et al. Methicillin-Resistant Staphylococcus aureus CC398 in humans and pigs in Norway: A “One Health" perspective on introduction and transmission. Clin. Infect. Dis. 2016, 63, 1431-1438. [CrossRef] [PubMed]

124. Cernicchiaro, N.; Pearl, D.L.; Ghimire, S.; Gyles, C.L.; Johnson, R.P.; LeJeune, J.T.; Ziebell, K.; McEwen, S.A. Risk factors associated with Escherichia coli O157:H7 in Ontario beef cow-calf operations. Prev. Vet. Med. 2009, 92, 106-115. [CrossRef] [PubMed]

125. Snow, L.C.; Warner, R.G.; Cheney, T.; Wearing, H.; Stokes, M.; Harris, K.; Teale, C.J.; Coldham, N.G. Risk factors associated with extended spectrum beta-lactamase Escherichia coli (CTX-M) on dairy farms in North West England and North Wales. Prev. Vet. Med. 2012, 106, 225-234. [CrossRef] [PubMed]

126. Schmithausen, R.M.; Schulze-Geisthoevel, S.V.; Stemmer, F.; El-Jade, M.; Reif, M.; Hack, S.; Meilaender, A.; Montabauer, G.; Fimmers, R.; Parcina, M.; et al. Analysis of transmission of MRSA and ESBL-E among pigs and farm personnel. PLoS ONE 2015, 10, e0138173. [CrossRef] [PubMed]

127. Broens, E.M.; Graat, E.A.; Van der Wolf, P.J.; Van de Giessen, A.W.; De Jong, M.C. Prevalence and risk factor analysis of livestock associated MRSA-positive pig herds in The Netherlands. Prev. Vet. Med. 2011, 102, 41-49. [CrossRef] [PubMed]

128. Schmithausen, R.M.; Kellner, S.R.; Schulze-Geisthoevel, S.V.; Hack, S.; Engelhart, S.; Bodenstein, I.; Al-Sabti, N.; Reif, M.; Fimmers, R.; Körber-Irrgang, B.; et al. Eradication of methicillin-resistant Staphylococcus aureus and of Enterobacteriaceae expressing extended-spectrum beta-lactamases on a model pig farm. Appl. Environ. Microbiol. 2015, 81, 7633-7643. [CrossRef] [PubMed]

129. Mannion, C.; Leonard, F.C.; Lynch, P.B.; Egan, J. Efficacy of cleaning and disinfection on pig farms in Ireland. Vet. Rec. 2007, 161, 371-375. [CrossRef] [PubMed]

130. Heinemann, C.; Steinhoff-Wagner, J.; Petersen, B. Evaluation of methods for determining cleaning performances in pig stables. J. Anim. Sci. 2017, 95, 48. [CrossRef]

131. Wellington, E.M.; Boxall, A.B.; Cross, P.; Feil, E.J.; Gaze, W.H.; Hawkey, P.M.; Johnson-Rollings, A.S.; Jones, D.L.; Lee, N.M.; Otten, W.; et al. The role of the natural environment in the emergence of antibiotic resistance in gram-negative bacteria. Lancet Infect. Dis. 2013, 13, 155-165. [CrossRef] 
132. Young, J.S.; Gormley, E.; Wellington, E.M. Molecular detection of Mycobacterium bovis and Mycobacterium bovis BCG (Pasteur) in soil. Appl. Environ. Microbiol. 2005, 71, 1946-1952. [CrossRef] [PubMed]

133. Gaze, W.H.; Burroughs, N.; Gallagher, M.P.; Wellington, E.M. Interactions between Salmonella typhimurium and Acanthamoeba polyphaga, and observation of a new mode of intracellular growth within contractile vacuoles. Microb. Ecol. 2003, 46, 358-369. [CrossRef] [PubMed]

134. Beuchat, L.R. Ecological factors influencing survival and growth of human pathogens on raw fruits and vegetables. Microbes Infect. 2002, 4, 413-423. [CrossRef]

135. Hiroi, M.; Harada, T.; Kawamori, F.; Takahashi, N.; Kanda, T.; Sugiyama, K.; Masuda, T.; Yoshikawa, Y.; Ohashi, N. A survey of $\beta$-lactamase-producing Escherichia coli in farm animals and raw retail meat in Shizuoka Prefecture, Japan. Jpn. J. Infect. Dis. 2011, 64, 153-155. [PubMed]

136. Blanc, V.; Mesa, R.; Saco, M.; Lavilla, S.; Prats, G.; Miró, E.; Navarro, F.; Cortés, P.; Llagostera, M. ESBLand plasmidic class $\mathrm{C}$ beta-lactamase-producing E. coli strains isolated from poultry, pig and rabbit farms. Vet. Microbiol. 2006, 118, 299-304. [CrossRef] [PubMed]

137. Mesa, R.J.; Blanc, V.; Blanch, A.R.; Cortés, P.; González, J.J.; Lavilla, S.; Miró, E.; Muniesa, M.; Saco, M.; Tórtola, M.T.; et al. Extended-spectrum beta-lactamase-producing Enterobacteriaceae in different environments (humans, food, animal farms and sewage). J. Antimicrob. Chemother. 2006, 58, 211-215. [CrossRef] [PubMed]

138. Heuer, H.; Schmitt, H.; Smalla, K. Antibiotic resistance gene spread due to manure application on agricultural fields. Curr. Opin. Microbiol. 2011, 14, 236-243. [CrossRef] [PubMed]

139. Müller, W.; Wieser, P.; Woiwode, J. Zur Größe koloniebildender Einheiten in der Stallluft. Berl. Münch. Tierärztl. Wschr. 1977, 90, 6-11.

140. Green, C.F.; Gibbs, S.G.; Tarwater, P.M.; Mota, L.C.; Scarpino, P.V. Bacterial plume emanating from the air surrounding swine confinement operations. J. Occup. Environ. Hyg. 2006, 3, 9-15. [CrossRef] [PubMed]

141. Hartung, J.; Seedorf, J.; Trickl, T.; Gronauer, H. Emission of particulates from a pig farm with central air exhaust in the pig stall. Deutsche Tierarztliche Wochenschrift 1998, 105, 244-245. [PubMed]

142. Zucker, B.A.; Trojan, S.; Müller, W. Airborne gram-negative bacterial flora in animal houses. J. Vet. Med. B Infect. Dis. Vet. Public Health 2000, 47, 37-46. [CrossRef] [PubMed]

143. Künneken, J. Simulation der Tier-Bakterium-Umwelt-Interaktion im Biotop "Abferkelstall"; University of Bonn: Bonn, Germany, 1991.

144. Hartung, J.; Whyte, R. Erfassung und Bewertung von Luftverunreinigungen in der Nutztierhaltung. Atemwegs-Lungenkr. 1994, 20, 17-25.

145. Venglovský, J.; Gregová, G.; Kmet', V.; Sasáková, N. Detection of airborne microorganisms and antibiotic resistance from animal housing facilities. In Proceedings of the XVth International Congress of the International Society for Animal Hygiene, Vienna, Austria, 12-16 August 2011; pp. 813-815.

146. Hilliger, H.G. Determination of bacterial flora in stall air. Zentralbl Veterinarmed B 1984, 31, 493-504. [CrossRef] [PubMed]

147. Benbough, J.E. Death mechanisms in airborne Escherichia coli. J. Gen. Microbiol. 1967, 47, 325-333. [CrossRef] [PubMed]

148. Gundermann, K.O. Life-span of bacterial strains in dust as influenced by various degrees of air humidity. Zentralbl Bakteriol Orig B 1972, 156, 422-429. [PubMed]

149. Hoffmann, D.H. Experimental endogenous inflammation of the internal eye by Candida albicans. Ophthalmoscopic, histological and microbiological studies on the course of the infection in rabbits. Ophthalmologica 1966, 151, 1-84. [PubMed]

150. Weese, J.S.; DaCosta, T.; Button, L.; Goth, K.; Ethier, M.; Boehnke, K. Isolation of methicillin-resistant Staphylococcus aureus from the environment in a veterinary teaching hospital. J. Vet. Intern. Med. 2004, 18, 468-470. [CrossRef] [PubMed]

151. Gibbs, S.G.; Green, C.F.; Tarwater, P.M.; Scarpino, P.V. Airborne antibiotic resistant and nonresistant bacteria and fungi recovered from two swine herd confined animal feeding operations. J. Occup. Environ. Hyg. 2004, 1, 699-706. [CrossRef] [PubMed]

152. Bos, M.E.; Verstappen, K.M.; van Cleef, B.A.; Dohmen, W.; Dorado-García, A.; Graveland, H.; Duim, B.; Wagenaar, J.A.; Kluytmans, J.A.; Heederik, D.J. Transmission through air as a possible route of exposure for MRSA. J. Expo. Sci. Environ. Epidemiol. 2016, 26, 263-269. [CrossRef] [PubMed] 
153. Heinemann, C.; Schmithausen, R.M.; Sib, E.; Meyer, I.; Petersen, B.; Steinhoff-Wagner, J. Preventive effect of nasal lavage with physiologic saline on the colonization with MRSA after working in porcine stable. J. Anim. Sci. 2017, 95, 250. [CrossRef]

154. Bos, M.E.; Taverne, F.J.; van Geijlswijk, I.M.; Mouton, J.W.; Mevius, D.J.; Heederik, D.J.; SDa, N.V.M.A. Consumption of antimicrobials in pigs, veal calves, and broilers in the Netherlands: Quantitative results of nationwide collection of data in 2011. PLoS ONE 2013, 8, e77525. [CrossRef] [PubMed]

155. Wenke, C.; Pospiech, J.; Reutter, T.; Altmann, B.; Truyen, U.; Speck, S. Impact of different supply air and recirculating air filtration systems on stable climate, animal health, and performance of fattening pigs in a commercial pig farm. PLoS ONE 2018, 13, e0194641. [CrossRef] [PubMed]

156. Laube, H.; Friese, A.; von Salviati, C.; Guerra, B.; Rösler, U. Transmission of ESBL/AmpC-producing Escherichia coli from broiler chicken farms to surrounding areas. Vet. Microbiol. 2014, 172, 519-527. [CrossRef] [PubMed]

157. Von Salviati, C.; Laube, H.; Guerra, B.; Roesler, U.; Friese, A. Emission of ESBL/AmpC-producing Escherichia coli from pig fattening farms to surrounding areas. Vet. Microbiol. 2015, 175, 77-84. [CrossRef] [PubMed]

158. Dohmen, W.; Schmitt, H.; Bonten, M.; Heederik, D. Air exposure as a possible route for ESBL in pig farmers. Environ. Res. 2017, 155, 359-364. [CrossRef] [PubMed]

159. Laube, H.; Friese, A.; von Salviati, C.; Guerra, B.; Käsbohrer, A.; Kreienbrock, L.; Roesler, U. Longitudinal monitoring of extended-spectrum-beta-lactamase/AmpC-producing Escherichia coli at German broiler chicken fattening farms. Appl. Environ. Microbiol. 2013, 79, 4815-4820. [CrossRef] [PubMed]

160. Hoffmann, A. Presence of CTX-M-1 Group Extended-Spectrum-ß-Lactamase in Dust from Dutch Pig Farms; Utrecht University: Utrecht, The Netherlands, 2014.

161. Lupo, A.; Coyne, S.; Berendonk, T.U. Origin and evolution of antibiotic resistance: The common mechanisms of emergence and spread in water bodies. Front. Microbiol. 2012, 3, 18. [CrossRef] [PubMed]

162. Baquero, F.; Martínez, J.L.; Cantón, R. Antibiotics and antibiotic resistance in water environments. Curr. Opin. Biotechnol. 2008, 19, 260-265. [CrossRef] [PubMed]

163. Coleman, B.L.; Salvadori, M.I.; McGeer, A.J.; Sibley, K.A.; Neumann, N.F.; Bondy, S.J.; Gutmanis, I.A.; McEwen, S.A.; Lavoie, M.; Strong, D.; et al. The role of drinking water in the transmission of antimicrobial-resistant E. coli. Epidemiol. Infect. 2012, 140, 633-642. [CrossRef] [PubMed]

164. Schwartz, T.; Kohnen, W.; Jansen, B.; Obst, U. Detection of antibiotic-resistant bacteria and their resistance genes in wastewater, surface water, and drinking water biofilms. FEMS Microbiol. Ecol. 2003, 43, 325-335. [CrossRef] [PubMed]

165. Mulamattathil, S.G.; Esterhuysen, H.A.; Pretorius, P.J. Antibiotic-resistant gram-negative bacteria in a virtually closed water reticulation system. J. Appl. Microbiol. 2000, 88, 930-937. [PubMed]

166. Kaspar, C.W.; Burgess, J.L.; Knight, I.T.; Colwell, R.R. Antibiotic resistance indexing of Escherichia coli to identify sources of fecal contamination in water. Can. J. Microbiol. 1990, 36, 891-894. [CrossRef] [PubMed]

167. Ozgumus, O.B.; Celik-Sevim, E.; Alpay-Karaoglu, S.; Sandalli, C.; Sevim, A. Molecular characterization of antibiotic resistant Escherichia coli strains isolated from tap and spring waters in a coastal region in Turkey. J. Microbiol. 2007, 45, 379-387. [PubMed]

168. Gao, P.; Munir, M.; Xagoraraki, I. Correlation of tetracycline and sulfonamide antibiotics with corresponding resistance genes and resistant bacteria in a conventional municipal wastewater treatment plant. Sci. Total Environ. 2012, 421-422, 173-183. [CrossRef] [PubMed]

169. Madec, J.Y.; Haenni, M.; Ponsin, C.; Kieffer, N.; Rion, E.; Gassilloud, B. Sequence Type 48 Escherichia coli Carrying the blaCTX-M-1 IncI1/ST3 Plasmid in Drinking Water in France. Antimicrob. Agents Chemother. 2016, 60, 6430-6432. [CrossRef] [PubMed]

170. Zarfel, G.; Lipp, M.; Gürtl, E.; Folli, B.; Baumert, R.; Kittinger, C. Troubled water under the bridge: Screening of River Mur water reveals dominance of CTX-M harboring Escherichia coli and for the first time an environmental VIM-1 producer in Austria. Sci. Total Environ. 2017, 593-594, 399-405. [CrossRef] [PubMed]

171. Kittinger, C.; Lipp, M.; Baumert, R.; Folli, B.; Koraimann, G.; Toplitsch, D.; Liebmann, A.; Grisold, A.J.; Farnleitner, A.H.; Kirschner, A.; et al. Antibiotic resistance patterns of pseudomonas spp. isolated from the River Danube. Front. Microbiol. 2016, 7, 586. [CrossRef] [PubMed]

172. LeJeune, J.T.; Besser, T.E.; Merrill, N.L.; Rice, D.H.; Hancock, D.D. Livestock drinking water microbiology and the factors influencing the quality of drinking water offered to cattle. J. Dairy Sci. 2001, 84, 1856-1862. [CrossRef] 
173. LeJeune, J.T.; Besser, T.E.; Hancock, D.D. Cattle water troughs as reservoirs of Escherichia coli O157. Appl. Environ. Microbiol. 2001, 67, 3053-3057. [CrossRef] [PubMed]

174. Pletinckx, L.J.; Verhegghe, M.; Dewulf, J.; Crombé, F.; De Bleecker, Y.; Rasschaert, G.; Goddeeris, B.M.; De Man, I. Screening of poultry-pig farms for methicillin-resistant Staphylococcus aureus: Sampling methodology and within herd prevalence in broiler flocks and pigs. Infect. Genet. Evol. 2011, 11, 2133-2137. [CrossRef] [PubMed]

175. Porrero, M.C.; Mentaberre, G.; Sánchez, S.; Fernández-Llario, P.; Casas-Díaz, E.; Mateos, A.; Vidal, D.; Lavín, S.; Fernández-Garayzábal, J.F.; Domínguez, L. Carriage of Staphylococcus aureus in free-living wild animals in Spain. Appl. Environ. Microbiol. 2014. [CrossRef] [PubMed]

176. van der Wolf, P.J.; Rothkamp, A.; Junker, K.; de Neeling, A.J. Staphylococcus aureus (MSSA) and MRSA (CC398) isolated from post-mortem samples from pigs. Vet. Microbiol. 2012, 158, 136-141. [CrossRef] [PubMed]

177. Exner, M.; Kramer, A.; Lajoie, L.; Gebel, J.; Engelhart, S.; Hartemann, P. Prevention and control of health care-associated waterborne infections in health care facilities. Am. J. Infect. Control 2005, 33, S26-S40. [CrossRef] [PubMed]

178. Hartung, J. Rules to control drinking water supply systems in livestock farming. Deutsche Tierarztliche Wochenschrift 2000, 107, 302-304. [PubMed]

179. Hartung, J.; Kamphues, J. Do we need regulation of drinking water for animals? Recommendations for the water supply of farm animals and pets. Deutsche Tierarztliche Wochenschrift 2000, 107, 343-345. [PubMed]

180. Jutkina, J.; Marathe, N.P.; Flach, C.F.; Larsson, D.G.J. Antibiotics and common antibacterial biocides stimulate horizontal transfer of resistance at low concentrations. Sci. Total Environ. 2018, 616-617, 172-178. [CrossRef] [PubMed]

181. Hölzel, C.S.; Schwaiger, K.; Harms, K.; Küchenhoff, H.; Kunz, A.; Meyer, K.; Müller, C.; Bauer, J. Sewage sludge and liquid pig manure as possible sources of antibiotic resistant bacteria. Environ. Res. 2010, 110, 318-326. [CrossRef] [PubMed]

182. Ben Said, L.; Jouini, A.; Klibi, N.; Dziri, R.; Alonso, C.A.; Boudabous, A.; Ben Slama, K.; Torres, C. Detection of extended-spectrum beta-lactamase (ESBL)-producing Enterobacteriaceae in vegetables, soil and water of the farm environment in Tunisia. Int. J. Food Microbiol. 2015, 203, 86-92. [CrossRef] [PubMed]

183. Purohit, M.R.; Chandran, S.; Shah, H.; Diwan, V.; Tamhankar, A.J.; Stålsby Lundborg, C. Antibiotic resistance in an Indian rural community: A 'One-Health' observational study on commensal coliform from humans, animals, and water. Int. J. Environ. Res. Public Health 2017, 14, 386. [CrossRef] [PubMed]

184. Vital, P.G.; Zara, E.S.; Paraoan, C.E.M.; Dimasupil, A.Z.; Abello, J.J.M.; Santos, I.T.G.; Rivera, W.L. Antibiotic resistance and extended-spectrum Beta-Lactamase production of Escherichia coli isolated from irrigation waters in selected urban farms in metro Manila, Philippines. Water 2018, 10, 548. [CrossRef]

185. Zurfluh, K.; Power, K.A.; Klumpp, J.; Wang, J.; Fanning, S.; Stephan, R. A novel Tn3-like composite transposon harboring blaVIM-1 in Klebsiella pneumoniae spp. pneumoniae isolated from river water. Microb. Drug Resist. 2015, 21, 43-49. [CrossRef] [PubMed]

186. Moore, J.E.; Watabe, M.; Millar, B.C.; Loughrey, A.; McCalmont, M.; Goldsmith, C.E.; Heaney, J.C.; Buckley, T.; Egan, C.; McDowell, D.A.; et al. Screening of clinical, food, water and animal isolates of Escherichia coli for the presence of blaCTX-M extended spectrum beta-lactamase (ESBL) antibiotic resistance gene loci. Ulster Med. J. 2010, 79, 85-88. [PubMed]

187. Ikegbunam, M.N.; Anagu, L.O.; Iroha, I.R.; Ejikeugwu, C.E.; Esimone, C.O. Abattoirs as non-hospital source of extended spectrum beta lactamase producers: Confirmed by the double disc synergy test and characterized by matrix-assisted laser desorption/ionization time of flight mass spectrometry. PLoS ONE 2014, 9, e94461. [CrossRef] [PubMed]

188. Johnson, J.R.; Sannes, M.R.; Croy, C.; Johnston, B.; Clabots, C.; Kuskowski, M.A.; Bender, J.; Smith, K.E.; Winokur, P.L.; Belongia, E.A. Antimicrobial drug-resistant Escherichia coli from humans and poultry products, Minnesota and Wisconsin, 2002-2004. Emerg. Infect. Dis. 2007, 13, 838-846. [CrossRef] [PubMed]

189. Vincent, C.; Boerlin, P.; Daignault, D.; Dozois, C.M.; Dutil, L.; Galanakis, C.; Reid-Smith, R.J.; Tellier, P.P.; Tellis, P.A.; Ziebell, K.; et al. Food reservoir for Escherichia coli causing urinary tract infections. Emerg. Infect. Dis. 2010, 16, 88-95. [CrossRef] [PubMed] 
190. Lavilla, S.; González-López, J.J.; Miró, E.; Domínguez, A.; Llagostera, M.; Bartolomé, R.M.; Mirelis, B.; Navarro, F.; Prats, G. Dissemination of extended-spectrum beta-lactamase-producing bacteria: The food-borne outbreak lesson. J. Antimicrob. Chemother. 2008, 61, 1244-1251. [CrossRef] [PubMed]

191. Normanno, G.; Dambrosio, A.; Lorusso, V.; Samoilis, G.; Di Taranto, P.; Parisi, A. Methicillin-resistant Staphylococcus aureus (MRSA) in slaughtered pigs and abattoir workers in Italy. Food Microbiol. 2015, 51, 51-56. [CrossRef] [PubMed]

192. Sommer, M. Epidemiologische Untersuchungen zur Tiergesundheit in Schweinezuchtbeständen unter besonderer Berücksichtigung von Managementfaktoren und des Einsatzes von Antibiotika und Homöopathika; Hanover University: Hanover, Germany, 2009.

193. Walker, B.; Holling, C.S.; Carpenter, S.; Kinzig, A. Resilience, adaptability and transformability in social-ecological systems. Ecol. Soc. 2004, 5, 9. [CrossRef]

194. Rauw, W.M.; Kanis, E.; Noordhuizen-Stassen, E.N.; Grommers, F.J. Undesirable side effects of selection for high production efficiency in farm animals: A review. Livest. Prod. Sci. 1998, 56, 15-33. [CrossRef]

195. Tenhagen, B.-A.; Fetsch, A.; Alt, K.; Käsbohrer, A.; Bräunig, A.; Appel, B. MRSA in herds of fattening pigs in Germany-Associated risk factors. In Proceedings of the Safe Pork 2009, Québec, QC, Canada, 30 September-2 October 2009.

196. Thielen, T.L.; Castle, S.S.; Terry, J.E. Anterior ocular infections: An overview of pathophysiology and treatment. Ann. Pharmacother. 2000, 34, 235-246. [CrossRef] [PubMed]

197. Steinhoff-Wagner, J. Ethische Zielkonflikte aus agrarwissenschaftlicher Perspektive. 2018; unpublished data.

198. Hörügel, K. Tiergesundheitsmanagement in der Schweinehaltung. Schriftenreihe der Sächsischen Landesanstalt für Landwirtschaft 2001, 7, 63-67.

199. Böckel, V. Untersuchungen zur quantitativen Bewertung der Tiergesundheit von Schweinebeständen; Hanover University: Hanover, Germany, 2008.

200. Berns, G. Einbindung von Check-Listen und mobilen Analyselabor in Beratungskonzepte zur Erweiterung von Gesundheitsvorsorge- und Qualitätsmanagementsystemen in der Schweinefleischerzeugung; University of Bonn: Bonn, Germany, 1996.

201. Düsseldorf, S. Concept of key Performance Indicators Controlling Consumer Oriented Quality and Herd Health Management in a Bavarian Pork Chain; Univertiy of Bonn: Bonn, Germany, 2013.

202. Ellebrecht, A. Nutzenbetrachtung Internetbasierter Informationssysteme im Einzel- und Überbetrieblichen Gesundheitsmanagement; University of Bonn: Bonn, Germany, 2008.

203. Ellebrecht, S. Application Concept for Combined Preventive Quality Management methods in inter-Enterprise Health Management in Pork Chains; University of Bonn: Bonn, Germany, 2012.

204. Gymnich, S. Haptoglobin als Screeningparameter im Gesundheitsmanagement von Ferkelaufzuchtbetrieben; University of Bonn: Bonn, Germany, 2001.

205. Klauke, T. Risk Based Approach towards More Sustainablilty in European Pig Production; University of Bonn: Bonn, Germany, 2012.

206. Mack, A. Konzeption für Die Anwendung Computergestützter Techniken im Gesundheitsmanagement Fleischerzeugender Ketten; University of Bonn: Bonn, Germany, 2009.

207. Schütz, V. Modell zur Planung von Dienstleistungen für das Überbetriebliche Gesundheitsmanagement in der Fleischwirtschaft; University of Bonn: Bonn, Germany, 2009.

208. Welz, M. Bewertung von Erkrankungen als Qualitätshemmende Faktoren mit Hilfe der Fehler-Möglichkeits- und Einfluss-Analyse (FMEA) im Rahmen der Erzeugung von Qualitätsfleisch; Bonn University: Bonn, Germany, 1993.

209. Schulze Althoff, G. Konzept und Erprobung von Werkzeugen für Grenzüberschreitende, Kettenübergreifende Qualitätsmanagementsysteme in der Schweinefleischerzeugung; University of Bonn: Bonn, Germany, 2007.

210. Petersen, B.; Nüssel, M.; Hamer, M. Quality and risk management in agri-food chains. In European Review of Agricultural Economics; Wageningen Academic Publishers: Wageningen, The Netherlands, 2014; pp. 1-3.

211. Schulze Althoff, G.; Breuer, O.; Jaeger, F.; Petersen, B. Working together to improve early warning-Cross border approaches to advancing prevention concepts. Fleischwirtsch. Int. 2007, 2, 55-58.

212. Petersen, J.V.; Andersen, J.K.; Sørensen, F.; Knudsen, H. Food safety on the slaughterline: Inspection of pig heads. Vet. Rec. 2002, 150, 782-784. [CrossRef] [PubMed]

213. Petersen, B.; Spiller, A.; Theuvsen, L. Vom Viehmarkter zum Dienstleistungsprofi; GIQS: Bonn, Germany, 2010.

214. Lehnert, H. Animal health monitoring. TopAgrar 2009, 11, 12-17. 
215. Schiefer, G. Tracking, Tracing and Business Process Interests: A Framework for Analysis. In Proceedings of the 26th Conference of the International Association of Agricultural Economists, Queensland, Australia, 12-16 August 2006.

216. Van der Vorst, J. Effective Food Supply Chains. Generating, Modelling and Evaluating Supply Chain Scenarios; University Wageningen: Wageningen, The Netherlands, 2000.

217. Petersen, B.; Lehnert, S. Qualitätsmanagement Maßgeschneidert für die Agrar- und Ernährungswirtschaft; Rheinische Friedrich-Wilhelms-Universität Bonn, International FoodNetCenter: Bonn, Germany, 2017; Volume 1.

218. Ewers, C.; Bethe, A.; Semmler, T.; Guenther, S.; Wieler, L.H. Extended-spectrum $\beta$-lactamase-producing and AmpC-producing Escherichia coli from livestock and companion animals, and their putative impact on public health: A global perspective. Clin. Microbiol. Infect. 2012, 18, 646-655. [CrossRef] [PubMed]

219. Ferreira, J.P.; Anderson, K.L.; Correa, M.T.; Lyman, R.; Ruffin, F.; Reller, L.B.; Fowler, V.G. Transmission of MRSA between companion animals and infected human patients presenting to outpatient medical care facilities. PLoS ONE 2011, 6, e26978. [CrossRef] [PubMed]

220. Häsler, B. (NEOH) Network for Evaluation of One Health. Available online: http:/ /www.accelopment.com/ de/projects/neoh (accessed on 23 October 2018).

221. Steinhoff-Wagner, J.; Ilg, Y.; Tappe, E.-V.; Lehnert, S.; Lehnert, H.; Petersen, B. One Health-Konzepte und ihre Umsetzung_Forschungsprojekte, Hochschulausbildung und Netzwerkinitiativen; ATD: Bonn, Germany, 2017; Volume 2.

222. De Neeling, A.J.; van den Broek, M.J.; Spalburg, E.C.; van Santen-Verheuvel, M.G.; Dam-Deisz, W.D.; Boshuizen, H.C.; van de Giessen, A.W.; van Duijkeren, E.; Huijsdens, X.W. High prevalence of methicillin resistant Staphylococcus aureus in pigs. Vet. Microbiol. 2007, 122, 366-372. [CrossRef] [PubMed]

223. Dickhöfer, D. Haptoglobin als Screeningparameter für Atemwegserkrankungen des Schweines; University of Bonn and University of Veterinary Medicine Hannover: Hannover, Germany, 2002.

224. Lipperheide, C.; Knura, S.; Petersen, B. Sicherung der Regionalen Vermarktung von Ferkeln für Nordrhein-Westfälische Qualitätsfleischprogramme Durch die Einführung Überbetrieblicher Gesundheitsmanagementund Frühwarnsysteme; Lehr- und Forschungsschwerpunkt "Umweltverträgliche und Standortgerechte Landwirtschaft": Bonn, Germany, 1999.

225. BMEL. 16. AMG-Novelle des Arzneimittelgesetzes; BMELV: Bonn, Germany, 2014.

226. QS. Wenn es um Fleisch geht. Qualität. Warenkunde. Küchentechniken. Rezeptideen. In Qualitätssicherung. Vom Landwirt bis zur Ladentheke; QS: Bonn, Germany, 2011; Available online: https:/ /www.q-s.de/flip/ ratgeber_fleisch/files/assets / downloads / publication.pdf (accessed on 23 October 2018).

227. Merle, R.; Kösters, S.; May, T.; Portsch, U.; Blaha, T.; Kreienbrock, L. Serological Salmonella monitoring in German pig herds: Results of the years 2003-2008. Prev. Vet. Med. 2011, 99, 229-233. [CrossRef] [PubMed] 